University of Nebraska - Lincoln

DigitalCommons@University of Nebraska - Lincoln

Faculty Publications from The Water Center

Water Center, The

2006

\title{
Emerging Chemicals and Analytical Methods (2006)
}

\author{
Matthew C. Morley \\ MWH Americas, Sacramento, CA, mmorley2@yahoo.com \\ Daniel D. Snow \\ University of Nebraska-Lincoln, dsnow1@unl.edu \\ Chad Cecrle \\ University of Nebraska- Lincoln \\ Patrick Denning \\ University of Nebraska- Lincoln \\ Lindsey Miller \\ University of Nebraska- Lincoln
}

Follow this and additional works at: https://digitalcommons.unl.edu/watercenterpubs

Part of the Water Resource Management Commons

Morley, Matthew C.; Snow, Daniel D.; Cecrle, Chad; Denning, Patrick; and Miller, Lindsey, "Emerging Chemicals and Analytical Methods (2006)" (2006). Faculty Publications from The Water Center. 13. https://digitalcommons.unl.edu/watercenterpubs/13

This Article is brought to you for free and open access by the Water Center, The at DigitalCommons@University of Nebraska - Lincoln. It has been accepted for inclusion in Faculty Publications from The Water Center by an authorized administrator of DigitalCommons@University of Nebraska - Lincoln. 


\title{
Emerging Chemicals and Analytical
}

\section{Methods}

\author{
Matthew C. Morley ${ }^{1^{*}}$, Daniel D. Snow ${ }^{2}$, Chad Cecrle ${ }^{3}$, Patrick Denning $^{3}$, and Lindsey Miller ${ }^{3}$
}

${ }^{1 *}$ Senior Environmental Engineer, MWH Americas, 3321 Power Inn Road, Suite 300, Sacramento, CA 95826-3889; Tel. 916-924-8844; Fax. 916-924-3293; e-mail: mmorley2@yahoo.com

\begin{abstract}
${ }^{2}$ Assistant Professor and Director, Water Science Laboratory, University of Nebraska - Lincoln ${ }^{3}$ Graduate Student, Dept. of Civil Engineering, University of Nebraska - Lincoln
\end{abstract}

doi:10.2175/106143006X119143

This review summarizes peer-reviewed literature related to analysis, occurrence, and fate of emerging chemical contaminants in the water environment. The review focuses on the following broad categories of emerging contaminants: pharmaceuticals and personal care products (PPCPs); endocrine disrupting compounds (EDCs), including hormones, surfactants, and plasticizers; and brominated flame retardants (BFRs). Although many of the cited articles refer to multiple types of contaminants (particularly hormones and pharmaceuticals), each article is summarized in only one section. Articles pertaining to specific treatment methods, risk assessments, or biological effects are not included in this review, and articles covering disinfection byproducts (DBPs), fluorinated compounds, and organometallics are not reviewed as in past years. Because of the ever-increasing volume and scope of literature pertaining to emerging contaminants, this review should not be considered to be comprehensive; however, a broad range of literature that is relevant to environmental engineers and scientists is summarized.

Acronyms that are used in this review for contaminants and analytical methods are summarized in Tables 1 and 2, respectively. 
Table 1. Contaminant and Analyte Abbreviations.

\begin{tabular}{|c|c|c|c|}
\hline APE & alkylphenol polyethoxylate & HBCD & hexabromocyclododecane \\
\hline BDE-209 & decabromodiphenyl ether & NP & nonylphenol, or 4-tert-nonylphenol \\
\hline BFR & brominated flame retardant & NP1EO & 4-nonylphenol monoethoxylate \\
\hline BPA & $\begin{array}{l}\text { bisphenol A, or 4,4'- } \\
\text { isopropylidenediphenol }\end{array}$ & NP2EO & 4-nonylphenol diethoxylate \\
\hline $\mathrm{CBZ}$ & carbamazepine & NPEO or NPnEO & nonylphenol polyethoxylate $(\mathrm{n}=1$ to 17 ) \\
\hline CIP & ciprofloxacin & NSAID & non-steroidal anti-inflammatory drug \\
\hline CIT & citalopram & $\mathrm{OP}$ & 4-tert-octylphenol \\
\hline CTC & chlortetracycline & OTC & oxytetracycline \\
\hline DBP & di-n-butyl phthalate & PBDE & polybrominated diphenyl ether \\
\hline DEHP & $\begin{array}{l}\text { bis-(2-ethylhexyl) phthalate, or di(2- } \\
\text { ethylhexyl) phthalate }\end{array}$ & $\mathrm{PhAC}$ & Pharmaceutically active compound \\
\hline DES & diethylstilbestrol & РPCP & $\begin{array}{l}\text { pharmaceuticals and personal care } \\
\text { products }\end{array}$ \\
\hline $\mathrm{DnOP}$ & di-n-octyl phthalate & SDZ & sulfadiazine \\
\hline E1 & estrone & SMX & sulfamethazine \\
\hline E2 & 17 -estradiol & SMZ & sulfamethoxazole \\
\hline E3 & estriol & SPY & sulfapyridine \\
\hline EDC & endocrine disrupting compound & TBBPA & tetrabromobisphenol A \\
\hline EE2 & 17 -ethinylestradiol & $\mathrm{TC}$ & tetracycline \\
\hline
\end{tabular}

\section{General Reviews and Multiple Contaminants}

Several reviews of developments in environmental analytical chemistry were presented. Developments during 2003 and 2004 were reviewed by Koester and Moulik (2005), summarizing recently developed extraction, separation, and detection methodologies for trace level analysis of environmental contaminants. Analytical methods for some emerging contaminants were summarized. Richardson and Ternes (2005) provide a similar extensive review of emerging contaminants in analysis of water, briefly describing methods from 200 articles published in 2003-2004. The authors note that because of the sheer volume of work in this area, the review was confined to new emerging contaminants and environmental issues driving current research in this area. Overall trends in sample preparation include increased use of new solid phase and micro-extraction techniques, and new insitu derivatization methods. Liquid chromatography mass spectrometry (LC/MS) has become more widely used for analysis of emerging contaminants such as pharmaceuticals, hormones and other endocrine disrupters. Summaries of analytical methods for PPCPs, EDCs, and BFRs are included, as well as drinking water disinfection byproducts, organotins, and microorganisms. 
Table 2. Abbreviations of Analytical Terms.

\begin{tabular}{|c|l|c|l|}
\hline APCI & atmospheric pressure chemical ionization & MIP & molecularly imprinted polymer \\
\hline BFR & brominated flame retardant & MS & mass spectrometry \\
\hline BSTFA & $N, O$-bis(trimethylsilyl)trifluoroacetamide & MS/MS & tandem mass spectrometry \\
\hline DVB & divinylbenzene & MTBSTFA & $\begin{array}{l}N \text {-methyl- } N \text { - } \text { tert- } \\
\text { butyldimethylsilyl)trifluoroacetamide }\end{array}$ \\
\hline ELISA & enzyme-linked immunosorbent assay & MSTFA & $N$-methyl- $N$-(trimethylsilyl)trifluoroacetamide \\
\hline ESI & electrospray ionization & NCI & negative chemical ionization \\
\hline GC & gas chromatography & PDMS & poly(dimethylsiloxane) \\
\hline HPLC & high performance liquid chromatography & RYA & recombinant yeast assay \\
\hline ICP & inductively coupled plasma & SDVB & styrene divinylbenzene \\
\hline LC & liquid chromatography & SIM & selected ion monitoring \\
\hline LC/MS & liquid chromatography - mass spectrometry & SPE & solid phase extraction \\
\hline LOQ & limit of quantitation & SPME & solid phase microextraction \\
\hline MAE & microwave-assisted extraction & TOF & time of flight \\
\hline MEKC & micellar electrokinetic chromatography & YES & yeast estrogen screen \\
\hline
\end{tabular}

Sampling and Extraction. Passive accumulation devices (PAD) can be used for accumulating many contaminant types in the aquatic environment for detection at low ng/L levels (Stuer-Lauridsen, 2005). Emerging contaminants for which PADs have been developed include brominated diphenyl ethers, alkyl phenols, phthalates, and steroid hormones. Applications of PADs to analysis of pharmaceuticals has occurred relatively recently with development of sorbent phases for highly polar compounds. Comprehensive reviews of the history and current status of passive sampling techniques were presented by Namie nik et al. (2005) and Vrana et al. (2005). Methods that were summarized included SPME, semi-permeable membrane devices, and polar organic chemical integrated samplers (POCIS). Many of the methods have been used for or can be adapted to analysis of emerging contaminants in different environmental compartments. Future methods will include miniaturized devices, applications for a wider range of contaminants, and elimination of interferences.

The POCIS was found to be more sensitive than traditional water sampling for detecting and analyzing lowlevel organic wastewater contaminants that may be present at extremely low levels or present only transiently in surface waters (Alvarez et al., 2005). At two sites in a New Jersey watershed, 32 contaminants were detected using the POCIS, compared to $9-24$ in composite surface water samples, attributed to diminished detection limits afforded by conventional composite samples and the transient nature of the wastewater contaminant concentrations in surface water. POCIS are less expensive to deploy and collect than multiple composite or grab samples and appear to reproduce exposure conditions of aquatic organisms.

Many recently developed hydrophilic sorbents and monolithic materials that improve the extraction of polar 
analytes were reviewed by Fontanals et al. (2005). These materials effectively sorb polar analytes because of the polarity of the sorbent surface and the high surface area. These sorbents can be used for SPE applications for extracting trace levels of various emerging contaminants from water samples.

A method for simultaneous extraction of 10 phenolic EDCs (including NP, OP, BPA, and E2) and 11 acidic PPCPs from wastewater was developed (Lee et al., 2005a). The optimized method utilized anion exchange SPE for extraction and fractionation of analytes from acidified $(\mathrm{pH}=3)$ samples prior to derivatization and analysis by GC-MS. Estimated method detection limits ranged from $0.001-0.1 \mathrm{~g} / \mathrm{L}$.

Castiglioni et al. (2005) present a method for analysis of 30 pharmaceuticals and steroids in wastewater using reverse phase and cation exchange SPE with LC/MS/MS with ESI using negative ion mode. Analytes were divided into 2 groups: one group was extracted with a mixed mode cation exchange cartridge (Oasis $\mathrm{MCX}$ ) after acidification to $\mathrm{pH}=2$, while the other was extracted with the Lichrolute EN cartridge at neutral pH. Recoveries ranged between 32 and $131 \%$ and method detection limits ranged from 0.1 to $\sim 5$ ng/L. Nineteen compounds were detected in analysis of effluent from 8 WWTPs in Italy at concentrations up to $\sim 2,000 \mathrm{ng} / \mathrm{L}$.

Analysis. Farre et al. (2005) reviewed numerous biological methods for screening pollutants in aqueous samples. Methods that were reviewed included bioassays (including assays for estrogenicity), immunoassays, and sensors. Specific methods were cited for bisphenol A, nonylphenols, and octylphenol. Proll et al. (2005) presented a brief review of automated biosensors that can be used for detecting contaminants in water samples, and Tschmelak et al. (2005) reported on the development of an optical biosensor that can be adapted for analysis of numerous PPCPs and EDCs in water samples. The immunoassay method is fully automated, requires no sample pretreatment or preconcentration, and has a detection limit of $0.20 \mathrm{ng} / \mathrm{L}$ for estrone.

\section{Occurrence and Fate - Wastewater Treatment}

Systems. The solids retention time (SRT), which is the average length of time that microorganisms remain in a treatment system, governs conventional pollutant removal in common biological treatment processes, and was also found to have a significant influence on removal of emerging contaminants (Clara et al., 2005a). Removal of BPA, hormones (E1, E2, E3, and EE2), and several pharmaceuticals was studied in lab-scale and full-scale wastewater treatment systems. As SRT was increased, removals of most compounds increased, with the notable exception of CBZ. Their results suggest that the operation of existing wastewater treatment plants (WWTPs) can potentially be modified by increasing the SRT to $>10$ days to reduce the discharge of many emerging contaminants to receiving waters. The removals of multiple contaminants (estrogens, EDCs, and pharmaceuticals) in batch activated sludge experiments were assessed and a model accounting for losses due to biodegradation and sorption was developed (Urase and Kikuta, 2005). Partitioning behavior was related to chemical structure, and at neutral $\mathrm{pH}$, pharmaceuticals sorbed to lesser extent than EDCs including E1, E2, EE2, and BPA.

Occurrence and Fate - Surface Water and Sediment. Glassmeyer et al. (2005) systematically sampled and analyzed surface water at 10 locations upstream and downstream from 
U.S. WWTPs to determine whether wastewater contaminants may be used in place of indicator bacteria for human waste. Of 110 contaminants included in the analyses, 78 compounds were detected in at least one sample. Contaminants were generally highest in samples collected immediately downstream from WWTPs, suggesting that these or related chemicals may be useful indicators of wastewater contamination. Based on their behavior in this study and their use by humans, carbamazapine, diphenhydramine, and caffeine may be useful as a more rapid indicator of drinking water or recreational water quality.

Numerous emerging contaminants, including pharmaceuticals and plasticizers, were detected in surface water samples from the Rhine River, Germany (Schwarzbauer and Heim, 2005). DEHP and CBZ were detected at concentrations as high as $9,800 \mathrm{ng} / \mathrm{L}$ and $650 \mathrm{ng} / \mathrm{L}$, respectively. Several brominated compounds were also detected in surface water for the first time.

Occurrence and Fate - Sludges, Soil, and Groundwater. Sewage sludge can be beneficially reused, but the fate and potential risks of emerging contaminants that are land applied with sewage sludge are poorly understood (Overcash et al., 2005). As yet, there is no way to predict degradation and migration of PPCPs and EDCs that are applied to soil with biosolids or other wastes in land application systems.

Occurrence and Fate - Drinking Water Treatment Systems. In an extensive study of the fate of EDCs and PPCPs in bench-scale drinking water treatment processes, coagulation and lime softening removed very little of the EDCs and PPCPs, whereas powdered activated carbon (PAC) removed as much as $98 \%$ of some compounds (Westerhoff et al., 2005). Oxidation by common disinfectants (chlorine or ozone) reduced concentrations of some EDCs and PPCPs by more than $90 \%$. Based on results of the study, conventional drinking water treatment using only coagulation and chlorination would be ineffective in removing many of the contaminants studied.

\section{Pharmaceuticals and Personal Care Products}

Analytical Methods. Díaz-Cruz and Barceló (2005) and Barceló (2005) reviewed the literature related to analysis of antimicrobial compounds in environmental samples using liquid chromatography-tandem mass spectrometry (LC/MS/MS). They discuss methods published in 60 references with detection limits as low as $2 \mathrm{ng} / \mathrm{L}$. Sulfonamide, tetracycline, macrolide and fluoroquinolone antimicrobials are the most frequently detected pharmaceuticals in samples from sewage treatment plants, as well as surface and groundwater impacted by these substances. There is growing evidence that conventional wastewater treatment methods are not sufficient to remove antibiotics and other pharmaceuticals from waste streams.

State-of-the-art LC/MS/MS methods for detection of pharmaceuticals in environmental samples were reviewed by Petrovi et al. (2005). The review includes information on analytical methods and sample preparation from 53 references for analysis of analgesics, anti-inflammatories, -blockers, lipid regulators, antibiotics, psychiatric drugs, and other pharmaceutically active compounds (PhACs). These methods do not require derivatization, while still achieving detection limits as low as $1 \mathrm{ng} / \mathrm{L}$. In addition, and reported concentrations of several types of pharmaceuticals in wastewater effluents were summarized. Kim and Carlson 
(2005) reviewed LC/MS and LC/MS/MS methods for quantifying trace concentrations of PhACs in environmental samples. The review summarizes information from 71 references on sample preparation and extraction, separation and detection, and occurrence and fate of pharmaceuticals in the aquatic environment, soil, and sediment.

Stoob et al. (2005) provide extensive details of an online SPE system interfaced with LC/MS/MS for automated analysis of sulfonamide antibiotics and pesticides in surface water. A commercially available $\mathrm{X}-\mathrm{Y}-\mathrm{Z}$ autosampler is used for pre-concentrating $18-\mathrm{mL}$ volumes of aqueous standards and samples onto a Waters Oasis ${ }^{\mathrm{TM}}$ HLB concentrator cartridge and eluted directly onto an analytical column. Using a triple quadrupole mass spectrometer with ESI, the authors report detection limits ranging from 0.5 to $5 \mathrm{ng} / \mathrm{L}$ and recoveries from 87 to $111 \%$. Analysis of spring runoff from a watershed after application of manure fertilizer and pesticides show well-correlated concentrations of atrazine, sulfamethazine and sulcotrione at concentrations up to 60 , 2,000 and 2,200 $\mathrm{ng} / \mathrm{L}$ respectively.

Schlüsener and Bester (2005) describe a method to analyze steroid hormones, hormone conjugates, oral contraceptives, and macrolide antibiotics in unfiltered influents and effluents of sewage treatment plants (STPs) using styrene divinyl benzene extraction disks with size exclusion cleanup (SEC) to reduce matrix effects, followed by LC/MS/MS. The limits of detection were $0.6-1.8 \mathrm{ng} / \mathrm{L}$ for macrolide antibiotics. The maximum contaminant concentrations in a STP influent sample was $470 \mathrm{ng} / \mathrm{L}$ for estriol and 1,200 ng/L for erythromycin.

Sulfonamides, macrolides, fluoroquinolones, and caffeine in aqueous samples were simultaneously analyzed by ion trap MS (LC/MS/MS) (Batt and Aga, 2005). Analytes were extracted by SPE using Oasis HLB cartridges, and detection limits for the 13 antibiotics were $0.1-0.65 \mathrm{~g} / \mathrm{L}$ and $0.24 \mathrm{~g} / \mathrm{L}$, respectively. The method found clindamycin at $1.1 \mathrm{~g} / \mathrm{L}$ in a surface water sample and caffeine and several antibiotics at $0.1-1.3 \mathrm{~g} / \mathrm{L}$ in wastewater effluent samples. Sulfonamides, macrolides, and trimethoprim can be extracted from sewage sludge using pressurized liquid extraction $\left(100^{\circ} \mathrm{C}, 100 \mathrm{bar}\right)$ with a $1: 1$ mixture of methanol and water (Göbel et al., 2005a). SPE was used to clean up the extract prior to analysis by LC/MS/MS. The method had LOQ ranging from $3-41 \mathrm{~g} / \mathrm{kg}$ dry weight. A method consisting of SPE (Chromabond Tetracycline cartridges) followed by HPLC with fluorescence or MS detection was used for analysis of nine quinolone and fluoroquinolone antibiotics (Ferdig et al., 2005). With fluorescence detection, LOQs ranged from 11-62 ng/L, and with MS, LOQs were $0.3-7.5$ ng/L. Using this method, ciprofloxacin was detected at 395 $\mathrm{ng} / \mathrm{L}$ in a wastewater effluent; $28 \mathrm{ng} / \mathrm{L}$ in river water $20 \mathrm{~m}$ downstream of the discharge; and $230 \mathrm{~g} / \mathrm{kg}$ in sewage sludge.

Yang et al. (2005) describe a multi-residue method for analysis of 11 tetracycline and sulfonamide antibiotics in raw and treated waste water. The method requires acidification and extraction of a $120 \mathrm{~mL}$ sample using a $60 \mathrm{mg}$ Waters Oasis $^{\text {TM }}$ HLB SPE cartridge. Analysis of extracts was performed using an ion trap LC/MS/MS system with detection limits ranging from 0.03 to $0.07 \mathrm{~g} / \mathrm{L}$. Levels of antibiotics detected in untreated sewage ranged from 0.05 to $1.09 \mathrm{~g} / \mathrm{L}$ and from 0.06 to $0.21 \mathrm{~g} / \mathrm{L}$ in treated effluent. A related article by Cha et al. (2005) describes a method for analysis of polyether ionophore antibiotics by SPE and ion 
trap LC/MS/MS with ESI in positive mode, with method detection limits ranging from 0.03 to $0.05 \mathrm{~g} / \mathrm{L}$.

Azithromycin can be extracted from wastewater samples into methyl-t-butyl ether after addition of potassium carbonate (Koch et al., 2005). Using LC/MS analysis, the limit of quantitation in $10-\mathrm{mL}$ wastewater samples was $4.25 \mathrm{ng} / \mathrm{L}$. This method found azithromycin ranging from 430-14,900 $\mathrm{ng} / \mathrm{L}$ in municipal wastewater samples from northeast Kansas.

A rapid (23 min per sample) fluoroimmunoassay method was developed for detection of -lactam antibiotics in water samples (Benito-Peña et al., 2005). The method has a detection limit of $2.4 \mathrm{~g} / \mathrm{L}$, and was useful for analysis of amoxicillin, ampicillin, and penicillin V. There were no matrix effects on immunosensor, allowing direct and sensitive analysis of wastewater samples.

In LC-ESI-MS analysis of NSAIDs and lipid regulators, matrix effects in wastewater samples were due mostly to low molecular weight compounds $(<1 \mathrm{kDa})$ that account for most of the dissolved organic carbon and which can be removed by ultrafiltration (Kloepfer et al., 2005). Reducing the flow rate to the ESI interface by using a post-column splitting device was helpful in reducing matrix interferences and improving precision and accuracy.

A method utilizing LC with diode array and MS detection was developed and validated for analysis of six NSAIDs (diclofenac, diflunisal, fenoprofen, IBU, naproxen, and tolmetin) in water samples (Debska et al., 2005). Analytes were pre-concentrated using off-line SPE. In natural waters, diode array detection had limits of detection (LOD) ranging from $6-98 \mathrm{ng} / \mathrm{L}$, and MS detection yielded LOD of $0.05-0.9 \mathrm{ng} / \mathrm{L}$. A molecularly imprinted polymer (MIP) was prepared using IBU as the template molecule (Caro et al.,
2005). Because the MIP was cross-reactive with other NSAIDs structurally related to IBU, it could be used for extracting multiple NSAIDs (including naproxen, fenoprofen, diclofenac, and IBU) at low $\mathrm{g} / \mathrm{L}$ levels from water samples for analysis by HPLC-UV.

SPME for extraction of triclosan and related compounds (possible metabolites methyl triclosan, 2,4-dichloropehnol, and 2,3,4-trichlorophenol) was optimized by Canosa et al. (2005). Analytes were first extracted from the sample onto a polyacrylate fiber, then derivatized on-fiber with MTBSTFA and analyzed by GC-MS. Limits of quantification were lower than $10 \mathrm{ng} / \mathrm{L}$.

An HPLC-ICP-MS method was developed for simultaneous analysis of five platinum containing chemotherapy drugs (cisplatin, monoaquacisplatin, diaquacisplatin, carboplatin, and oxaliplatin) in environmental samples (Hann et al., 2005). Analyte separation was accomplished with a pentafluorophenylpropyl-functionalized silica gel column and an ammonium formate/water/methanol mobile phase, achieving detection limits of 0.9-0.15 $\mathrm{g} / \mathrm{L}$ for three of the analytes. The method was used to quantify levels of these chemotherapeutic agents in hospital wastewater and to study their stability. Iodinated x-ray contrast agents (amidotrizoic acid, iohexol, iomeprol, iopamidol, iopromide, and ioxitalamic acid) were separated by ion chromatography and detected by ICP-MS (Sacher et al., 2005). Without preconcentration, limits of detection in tap water were $0.02-$ $0.04 \mathrm{~g} / \mathrm{L}$ using a 1-mL sample loop.

Occurrence and Fate - Wastewater Treatment. The fate of human pharmaceuticals in WWTPs was reviewed by Jones et al. (2005c). Pharmaceuticals have a wide range of physical and chemical characteristics, as well as removal 
efficiencies during wastewater treatment. Because of incomplete removal, WWTP effluent is the largest contributor of PPCPs to surface waters, and despite much recent research, there are many questions remaining about the fate and effects of these contaminants. Joss et al. (2005) found significant removal of seven PhACs and two fragrances during full-scale biological wastewater treatment with nutrient removal and presented a method for estimating mass balances on micropollutants in WWTPs. Removals of the PhACs ranged from $<10 \%$ for $\mathrm{CBZ}$ to $>90 \%$ for IBU. Removal of PhACs was due mainly to biotransformation, whereas the most important removal mechanism for the fragrances was sorption onto sludge.

Several fluoroquinolone antibiotics, trimethoprim, sulfamethoxazole, and doxycycline were found in WWTP effluent and in sewage sludge at five locations in Sweden (Lindberg et al., 2005). Measured mass loading of these compounds correlated to estimated usage in the municipalities. In a survey of 9 quinolone antibiotics in wastewater and surface waters using LC/MS and LC with fluorescence detection, none of the compounds were detected in surface water samples; however, effluent from a WWTP in Michigan had 100 ng/L ofloxacin (Nakata et al., 2005). The WWTP was estimated to discharge about $4.8 \mathrm{~g} / \mathrm{d}$ of ofloxacin into the receiving water.

Five acidic pharmaceuticals (IBU, naproxen, ketoprofen, diclofenac and bezafibrate) were monitored in sewage treatment plants and receiving waters in Finland (Lindqvist et al., 2005). All five compounds were detected in WWTP influents, with IBU as high as $19 \mathrm{~g} / \mathrm{L}$. IBU was most easily treated (removal rates of $78-100 \%$ ), whereas diclofenac was most difficult to treat (removals of 9-60\%). All five compounds were detected in surface water downstream of wastewater discharge points at concentrations of 3.0-6.5 ng/L. Thomas and Foster (2005) measured the concentrations of five acidic pharmaceuticals, caffeine, and triclosan in different stages of waste water treatment using polymeric SPE followed by GC-MS of the silyl derivatives. Three treatment plants in Virginia were sampled at the influent, primary, secondary and final effluent stages. Secondary treatment was found to be the most important process of removal of these compounds, and removal by sorption to particulates was only significant for triclosan.

The distribution of CBZ, its metabolites, and caffeine between the solid and liquid phases throughout a secondary WWTP was studied by Miao et al. (2005). Only $29 \%$ of the influent CBZ (356.1 ng/L) was removed from the liquid phase in the plant that was studied; CBZ metabolites were not removed. In anaerobically digested biosolids, CBZ concentration on a dry weight basis was $258.1 \mathrm{~g} / \mathrm{kg}$. The influent to a WWTP in Spain serving a population of about 100,000 had detectable levels of several PPCPs, including the musk compounds galaxolide (2.1-3.4 g/L) and tonalide (0.9$1.7 \mathrm{~g} / \mathrm{L})$, IBU $(2.6-5.7 \mathrm{~g} / \mathrm{L})$, naproxen $(1.8-4.6 \mathrm{~g} / \mathrm{L})$, the antibiotic sulfamethoxazole $(\sim 0.6 \mathrm{~g} / \mathrm{L})$, the x-ray contrast compound iopromide (6-7 $\mathrm{g} / \mathrm{L})$, and the hormones E1 and E2 (both 2-3 ng/L) (Carballa et al., 2005). During primary treatment, about $40 \%$ of the musk compounds were removed; removals of other compounds were negligible. With the exceptions of estrone and iopromide, overall removal of each compound was up to $75 \%$, with most of the removal occurring during the conventional activated sludge process. Estrone concentrations increased as estradiol was aerobically biodegraded, and iopromide removal was negligible. 
Sulfamethoxazole (SMZ) can serve as a carbon and nitrogen source during aerobic biodegradation by acclimated microorganisms (Drillia et al., 2005a). In bench-scale sequencing batch reactor studies, SMZ was readily utilized only when other carbon and nitrogen sources (e.g., acetate or ammonia) were depleted. At initial concentrations of 20 g/L, sulfonamide antibiotics (SMX, SMZ, and sulfathiazole) were biodegraded more rapidly than trimethoprim in batch tests with sewage from various locations in a WWTP (Pérez et al., 2005). Sludge from an activated sludge aeration tank readily biodegraded the three sulfonamides with no lag time, but trimethoprim was unaltered during a 56-d test. In contrast, sludge from a nitrification process biodegraded trimethoprim in $<5 \mathrm{~d}$, while the sulfonamides were biodegraded somewhat slower. Eichhorn et al. (2005) utilized LC coupled with MS methods to characterize two trimethoprim metabolites produced by the nitrifying sludge. Both metabolites had a higher molecular weight than the parent compound, indicating the culture could oxidatively transform trimethoprim, but not degrade it.

In laboratory tests with activated sludge, Quintana et al. (2005) studied the biodegradation pathways and used LC/MS/MS to identify metabolites produced by aerobic biodegradation of IBU, ketoprofen, naproxen, diclofenac, and bezafibrate. For all compounds except ketoprofen, cometabolism appeared to be an important biodegradation pathway; ketoprofen could be used as a sole source of carbon and energy. Each of the test compounds produced multiple metabolites and was at least partially mineralized, though only IBU and naproxen appeared to be completely mineralized under aerobic conditions.
Membrane bioreactors (MBR) and the conventional activated sludge process operated at similar solids retention times achieved similar removal efficiencies for pharmaceuticals and EDCs, indicating that the ultrafiltration membranes used in MBRs provide no additional treatment advantage (Clara et al., 2005b). Biodegradation was the primary removal mechanism for IBU and bezafibrate, with $>90 \%$ removed; other substances such as CBZ were not removed.

Sorption was found to be the main removal mechanism of tetracycline in the activated sludge process (Kim et al., 2005). Tetracycline removal was $\geq 85 \%$ in lab-scale activated sludge tests at a solids retention time (SRT) of $10 \mathrm{~d}$, but $<80 \%$ at a SRT of $3 \mathrm{~d}$. Sorption and desorption tests also indicated that TC will readily desorb from activated sludge, which could pose a risk from land applied biosolids. Concentrations of sulfonamides, macrolides, trimethoprim, and their human metabolites ranged from $20-1,700 \mathrm{ng} / \mathrm{L}$ in the influent to Swiss wastewater treatment plants and $10-400 \mathrm{ng} / \mathrm{L}$ in tertiary effluents (Göbel et al., 2005b). For 5 of these compounds, sorption to activated sludge was generally low $\left(\mathrm{K}_{\mathrm{d}}<460 \mathrm{~L} / \mathrm{kg}\right)$, resulting in low concentrations sorbed to activated sludge (28$68 \mathrm{mg} / \mathrm{kg}$ dry weight) and digested sludge.

The antimicrobial additives triclosan and triclocarban were found to coexist in numerous surface water and wastewater samples taken in the vicinity of Baltimore, Maryland (Halden and Paull, 2005). Triclocarban has received relatively little research attention compared to triclosan, but over the study period, average triclocarban concentrations in raw wastewater were $6,700 \mathrm{ng} / \mathrm{L}$, with average removals of $98 \%$. These results are very similar to those for triclosan. 
Ozonation for wastewater effluent disinfection may oxidize pharmaceuticals and reduce mass loading to receiving streams (Huber et al., 2005a). Ozone doses of $\geq 2 \mathrm{mg} / \mathrm{L}$ resulted in $>90 \%$ removal of several pharmaceuticals at initial concentrations of $0.5-5 \mathrm{~g} / \mathrm{L}$, including macrolides, sulfonamides, estrogens, diclofenac, and naproxen, but resulted in lower removals of x-ray contrast media and some acidic PhACs.

Occurrence and Fate - Surface Water and Sediment. Pharmaceutical loading to the Arc River, France was found to be nearly constant throughout the year due to continuous wastewater inputs, in contrast to pesticide loading, which peaked during the spring (Comoretto and Chiron, 2005). PhACs were commonly detected at locations downstream of wastewater treatment plants. IBU was only sporadically detected in surface water, but $\mathrm{CBZ}$ and bezafibrate were detected at concentrations up to $1,150 \mathrm{ng} / \mathrm{L}$ and $780 \mathrm{ng} / \mathrm{L}$, respectively. Fono and Sedlak (2005) suggested that the chiral pharmaceutical propranolol, a beta-blocker, can be used as a tracer for raw and treated sewage. By analyzing the two enantiomers of propranolol, they found that raw wastewater and biologically treated wastewater have different ratios of the two enantiomers. Analysis of these enantiomers thus indicates whether surface water has been impacted by treated or untreated sewage.

Several PPCPs were identified in runoff from agricultural fields in Southern California that were irrigated with treated wastewater (Pedersen et al., 2005). Contaminants were detected in runoff from fields irrigated with secondary effluent, tertiary effluent, and effluent dominated stream water. Anti-inflammatories, antimicrobials, musks, insect repellants, flame retardants, and hormones were among the detected contaminants. The results of a 2-year study of antibiotics in fish hatcheries was reported by Dietz et al. (2005) and indicate more frequent occurrence of these compounds in from intensive hatcheries than samples from extensive hatcheries. Residues of ormetoprim, OTC, and sulphadimethoxine were higher in samples from intensive hatcheries than samples from extensive hatcheries, while sulphadimethoxine appeared to have the greatest half-life.

Enrofloxacin, a fluoroquinolone antibacterial, at an initial concentration of $25 \mathrm{~g} / \mathrm{L}$ rapidly degraded in aquatic mesocosms when exposed to sunlight, with a half life of about $0.8 \mathrm{~d}$ (Knapp et al., 2005). One of the main byproducts of enrofloxacin is ciprofloxacin, which also has significant antimicrobial activity. In laboratory and field mesocosm studies, Cardoza et al. (2005) found that CIP is photosensitive and readily sorbs to organic solids, particularly at low $\mathrm{pH}$ (neutral $\mathrm{pH}$ : $\mathrm{K}_{\mathrm{OC}}$ ranged from $13,900-20,500 \mathrm{~L} / \mathrm{kg}$; at $\mathrm{pH}$ 3.0, $\mathrm{K}_{\mathrm{OC}}$ ranged from $77,500-97,300 \mathrm{~L} / \mathrm{kg}$ ). In surface waters, photodegradation is likely to be an important CIP degradation mechanism, whereas adsorption will simply transfer CIP between phases.

Fluoxetine (FLX), an antidepressant, degrades in surface waters by direct and indirect photolysis when exposed to sunlight (Lam et al., 2005). For direct photolysis, the half-life of FLX was found to be 55.2 hours in deionized water; for indirect photolysis, the half lives ranged from $5.5-22$ hours in synthetic field waters. Citalopram (CIT), also an antidepressant, was degraded by simulated sunlight at $\mathrm{pH} 9$, but was stable over $30 \mathrm{~d}$ at $\mathrm{pH} 5$ and $\mathrm{pH} 7$ (Kwon and Armbrust, 2005). CIT half-lives ranged from $14 \mathrm{~d}$ in a natural water to $64 \mathrm{~d}$ in a buffer solution, indicating that 
photosensitization by constituents in natural waters enhances CIT photodegradation.

Aguera et al. (2005) utilized SPE and a combination of GC-MS and LC with time-of-flight MS to determine 13 solar photolysis products of diclofenac. Two different pathways for photolysis of diclofenac were proposed. Photodegradation of five pharmaceuticals (gemfibrozil, ibuprofen, ketoprofen, naproxen, and propranolol) and four estrogens was studied in river water by Lin and Reinhard (2005), who found halflives ranging from $1.1 \mathrm{~min}$ (propanolol) to $15 \mathrm{~h}$ (gemfibrozil and IBU). Estrogen half-lives were 2-3 hours.

A commonly used UV filter, 4-methylbenzylidene camphor (4-MBC), was detected in several Swiss lakes and rivers using semipermeable membrane devices (Buser et al., 2005). The isomeric composition in various environmental samples was dependent not only on the 4-MBC source, but also enantioselective processes that may occur in surface waters. 4-MBC and three other UV filters (benzophenone-3, ethylhexyl methoxy cinnamate, and octocrylene) were detected at low concentrations in Swiss lakes and rivers, with concentrations ranging from $<2-35 \mathrm{ng} / \mathrm{L}$ (Balmer et al., 2005). Inputs to surface waters included recreational activities and wastewater effluents.

Occurrence and Fate - Sludges, Soil, and Groundwater. Several antibiotics at $1-25 \mathrm{mg} / \mathrm{L}$, including sulfonamides, tetracyclines, lincomycin, and tylosin tartrate, partially inhibited anaerobic bacteria from swine waste lagoons by reducing methane production by $20-45 \%$ (Loftin et al., 2005). This inhibition may have adverse effects on treatment efficiency of animal wastes in anaerobic lagoons. Tylosin undergoes biotic and abiotic degradation in swine manure lagoons, but sorption to solids is a primary removal mechanism (Kolz et al., 2005a). Losses under aerobic conditions were generally much faster than under anaerobic conditions. $\mathrm{K}_{\mathrm{OC}}$ values for sorptin of tylosin onto swine manure solids ranged from $570-818 \mathrm{~L} / \mathrm{kg}$ (Kolz et al., 2005b). Tylosin is expected to be more mobile than tetracyclines, but less mobile than sulfonamides.

Veterinary antibiotics are applied to agricultural land as a contaminant in manure slurries. Aga et al. (2005) report on a 2-year fate and transport study of OTC in test plots fertilized with cattle manure. OTC was measured using ELISA screening tests and LC/MS/MS. The ELISA screen suggested that total tetracycline activity did not decline significantly over the study period while the LC/MS/MS results indicated that OTC concentrations declined to $50 \%$ of its initial concentration after 3 weeks. Very little oxytetracycline was detected in soil sampled below $5 \mathrm{~cm}$, and neither the parent nor is degradation products were detected in lysimeter samples from the test plots. In a lysimeter study of the fate of three antibiotics, only sulphachloropyridazine was detected in leachate (Kay et al., 2005a); two other antibiotics (a tetracycline and a macrolide) were not detected in leachate or soil.

Kay et al. (2005b) evaluated the mobility of three classes of veterinary antibiotics using soil column studies. OTC was relatively immobile in the test soils while sulphachloropyridazine was more easily leached. Manure application had relatively little impact on leaching rates. Runoff of these antibiotics from test plots treated with swine manure was greater from plots with compacted soils (Kay et al., 2005c). Sulphachloropyridazine and OTC were detected in surface runoff after $\sim 3 \mathrm{~mm}$ of rainfall, at peak concentrations of 703.2 and $71.1 \mathrm{~g} / \mathrm{L}$, respectively, while 
tylosin was not detected. Sulfamethazine and tetracycline were found to have very different leaching characteristics (Hamscher et al., 2005). Tetracycline was relatively immobile during a three-year field study at a site that was fertilized with liquid manure, accumulating to average concentrations $>150 \mathrm{~g} / \mathrm{kg}$ soil. In contrast, sulfamethazine was detected at concentrations up to $0.24 \mathrm{~g} / \mathrm{L}$ in groundwater samples from $1.4 \mathrm{~m}$ below ground surface.

A 155-d field study of CTC and tylosin A was performed to assess dissipation of these antibiotics from agricultural soils (Halling-Sørensen et al., 2005). After amendment with manure, initial concentrations of CTC ranged from 20-30 $\mathrm{g} / \mathrm{kg}$ soil and tylosin A ranged from 25-50 $\mathrm{g} / \mathrm{kg}$ soil. The half-lives of CTC and tylosin A were 25 and $67 \mathrm{~d}$, respectively, in a sandy loam soil and 34 and $49 \mathrm{~d}$, respectively, in a sandy soil. Over 102 days, only $1 \%$ of the veterinary antibiotic sulfadiazine (SDZ) was mineralized in a bovine manure slurry, whereas $82 \%$ was bound as an unextractable residue (Kreuzig and Höltge, 2005). Formation of the nonextractable residue reduced mobility when the manure was applied to soils, although the residual bioavailability is unclear. Sulfonamide antibiotics (sulfadiazine, sulfadimidine, and sulfamethoxazole) in runoff fertilized with liquid manure from test plots were mostly in the liquid phase, rather than sorbed to suspended particles in the runoff (Kreuzig et al., 2005).

Based on experiments in which OTC was sorbed to humic acids, MacKay and Canterbury (2005) suggested that organic matter in soils may be an important sorbent material affecting the fate and transport of antibiotics in soils. Sorption of OTC is also enhanced by complexation with iron oxide coatings on soil particles (Figueroa and MacKay, 2005).
OTC sorption to iron oxides has a maximum at $\mathrm{pH} \sim 8$. Cation exchange capacity, iron oxide content, and soil clay content have the strongest influence on sorption of OTC in soils with low organic carbon content $(<4 \%)$ (Jones et al., 2005a). In these sorption tests on 30 different soils, organic carbon was important only in soils with $9 \%$ organic carbon.

Sulfonamides may covalently bond to soil natural organic matter, thereby reducing their mobility and toxicity in the environment (Bialk et al., 2005). Sorption of three sulfonamide antimicrobials (SMZ, SMX, and SPY) to montmorillonite and kaolinite exhibited strong dependence on $\mathrm{pH}$, which affected sorbate speciation and characteristics of the clay (Gao and Pedersen, 2005). Cationic species were more strongly sorbed to montmorillonite than neutral species.

The adsorption and desorption characteristics of six pharmaceuticals (CBZ, propranolol, diclofenac sodium, clofibric acid, sulfamethoxazole, and ofloxacin) to two different soils were reported by Drillia et al. (2005b). Clofibric acid was weakly sorbed to the test soils, whereas ofloxacin was strongly sorbed and exhibited desorption hysteresis. Batch sorption experiments found that CBZ, diclofenac, and IBU weakly sorb to medium and fine grained sands with low organic content (Scheytt et al., 2005a). Distribution coefficients ranged from $0.21-5.32$ for $\mathrm{CBZ}$; 0.55-4.66 for diclofenac; and 0.18-1.69 for IBU. 1octanol/water partition coefficients for these compounds as well as clofribic acid and propyphenazone were also reported (Scheytt et al., 2005b). Log $\mathrm{K}_{\mathrm{OW}}$ values ranged from 1.51 for CBZ to 2.88 for clofibric acid. In oxic microcosm tests with a sediment with a low organic carbon content, ibuprofen was found to have low persistence, with $77 \%$ mineralization over $100 \mathrm{~d}$ (Loffler et al., 2005). Along with IBU, paracetomol 
and the IBU metabolite 2-hydroxyibuprofen were considered to have low persistence, whereas clofibric acid, diazepam, and CBZ were found to be highly persistent.

The presence of surfactants in wastewater may enhance the sorption of pharmaceuticals to aquifer solids, thereby reducing their mobility (Hari et al., 2005). In the absence of surfactants, sorption of acetaminophen and CBZ was negligible, but nonionic and cationic surfactants enhanced sorption of both of these compounds. A cationic surfactant enhanced the sorption of nalidixic acid but had negligible effect on sorption of norfloxacin; a nonionic surfactant did not influence sorption of either of these compounds.

Occurrence and Fate - Drinking Water. Reported concentrations of pharmaceutical compounds in finished drinking waters were reviewed by Jones et al. (2005b). Analgesics, antibiotics, antidepressants, and lipid regulators have been detected in drinking waters at concentrations up to the low hundreds of ng/L. Many questions remain on the possible health impacts, treatment methods, and future regulatory requirements for these compounds in drinking water.

A survey of French drinking water sources and finished drinking waters found multiple contaminants in surface waters and groundwaters, and four iodinated x-ray contrast media (iopamidol, ioxitalamic acid, diatrizoate, and iomeprol) in treated drinking water at concentrations between 11 and 60 ng/L (Bruchet et al., 2005). These compounds were noted to be the most resistant to all types of treatment, including granular activated carbon (GAC) adsorption and advanced oxidation processes, but they are considered non-toxic. Significant concentrations of PhACs were found in river water and at a drinking water treatment plant $32 \mathrm{~km}$ downstream of a Finnish WWTP, particularly during winter, when cold temperatures decreased removal rates (Vieno et al., 2005). Because of incomplete removal during GAC treatment, ibuprofen and ketoprofen were detected in finished drinking water at 8.5 and $8 \mathrm{ng} / \mathrm{L}$, respectively.

CIP reacts rapidly with both free and combined forms of chlorine, whereas enrofloxacin reacts very slowly with free chlorine and is unaffected by combined chlorine (Dodd et al., 2005). Huber et al. (2005b) found that sulfonamides, macrolides, phenazones, and estrogens are readily oxidized by chlorine dioxide $\left(\mathrm{ClO}_{2}\right)$, whereas many acidic and neutral pharmaceuticals were unreactive. Fewer pharmaceuticals reacted with $\mathrm{ClO}_{2}$ as compared to ozone under similar conditions, but $\mathrm{ClO}_{2}$ was more effective than free chlorine in oxidizing some compounds. Naproxen readily reacts with free chlorine, forming several disinfection byproducts (Boyd et al., 2005). Production of byproducts was dependent on $\mathrm{pH}$ and water chemistry, with faster reactions occurring at $\mathrm{pH} \leq 7$. Triclosan is rapidly oxidized by free chlorine, producing chloroform and three chlorinated phenoxyphenol compounds (Rule et al., 2005). Reaction rates were most rapid at $\mathrm{pH} 7$.

McDowell et al. (2005) investigated the by-products formed by oxidation of the anti-epileptic drug CBZ by ozone and $\mathrm{OH}$ radicals. $\mathrm{OH}$ radicals (rather than ozone) further oxidize the three by-products that were identified, but there is no available data on their biological effects. CBZ reacts relatively fast compared to other neutral pharmaceuticals tested, and a waterworks could estimate the CBZ by-product formation based on rate constants presented. 
YES assay, the Ishikawa bioassay was about 50 times more

Endocrine Disrupting Compounds - General Detection and Multiple Contaminants

Research on EDCs and their effects has produced thousands of journal articles over the last 10-15 years. Lessons that have been learned from these research efforts were summarized by Sumpter and Johnson (2005) and Sumpter (2005). Among these lessons, Sumpter and Johnson state WWTP effluents are a direct and continuous source of EDCs to the environment; thus, many aquatic organisms in receiving streams are continuously exposed to low levels of EDC mixtures. Greater degrees of wastewater treatment (i.e., nitrification/denitrification, tertiary treatment) generally correspond to lower effluent EDC concentrations. Degradation products of some synthetic EDCs, such as APEs, permethrin, and triclosan, can also have estrogenic effects; thus, estimation of potential risks must account for both parent compounds and their metabolites.

Analytical Methods. Beck et al. (2005) utilized Oasis HLB SPE cartridges to extract natural and synthetic estrogens (E1, E2, E3, and EE2), phytoestrogens (daidzein, genistein), and phenolic EDCs (BPA, NP, and OP) from 50-L marine water samples for simultaneous analysis by HPLC-ESI-MSMS. Method detection limits ranged from $0.02 \mathrm{ng} / \mathrm{L}$ for E1 to $1.0 \mathrm{ng} / \mathrm{L}$ for E3. Using this method, E1 and EE2 were detected at concentrations as high as 0.53 and $17 \mathrm{ng} / \mathrm{L}$, respectively, in surface water samples from the Baltic Sea.

The Ishikawa cell line bioassay, which measures stimulation of alkaline phosphatase activity in human endometrial adenocarcinoma cells, was applied to measuring estrogenic activity of sediments from five locations around Tokyo Bay (Hashimoto et al., 2005). As compared to the sensitive to 17 -estradiol and was not affected by sediment extract toxicity. Estrogenic activity ranging from 5.7 to 697 pg E2 equivalents/g sediment were found in the sediment samples, with the higher levels located near a WWTP.

A transgenic fish was developed for use as an environmental monitor of endocrine disrupting chemicals (Zeng et al., 2005). In male and juvenile transgenic fish, exposure to exogenous estrogenic compounds induces expression of green fluorescent protein (GFP). GFP expression was observed in live fish after induction by exposure to $0.5 \mu \mathrm{g} \mathrm{E} 2 / \mathrm{L}$.

A recombinant yeast bioassay was developed for analysis of androgenic activity in environmental samples (Michelini et al., 2005). The method utilizes a recombinant yeast which utilizes a bioluminescent reporter gene that responds to androgenic species. Testosterone was used as the reference androgen and was shown to produce a response down to a concentration of $10^{-11}$ moles/L. A set of bioluminescent yeast strains expressing human androgen receptor, estrogen receptor , (ER- ), and estrogen receptor

(ER- ) were developed for detection of estrogenic and androgenic compounds (Leskinen et al., 2005). Each of the strains expresses firefly luciferase upon induction, and the method can be used for testing environmental samples.

Pillon et al. (2005) developed complementary bioassays for detection of complex mixtures of estrogenic compounds in water and sediment samples. Compounds that have high affinity for ER- (e.g., natural and synthetic estrogens) often partition to the aqueous phase and were separated from those that have estrogenic activity via the aryl hydrdocarbon receptor (AhR) (e.g., polycyclic aromatic hydrocarbons or 
dioxins) using an agarose column with immobilized recombinant ER- . Both types of estrogenic EDCs were measured by luciferase gene expression with specific bioluminescent cell lines.

Occurrence and Fate - Wastewater Treatment. Jiang et al. (2005a,b) monitored several EDCs (including OP, NP, BPA, E1, and E2) at different locations in two secondary WWTPs. BPA consistently had the highest concentration in the influent (up to $890 \mathrm{ng} / \mathrm{L}$ ). Primary treatment had little effect on these compounds, but biological treatment provided partial removal. An Australian WWTP that included advanced treatment processes for nutrient removal reduced estrogenicity of treated wastewater by $95-98 \%$ (Leusch et al., 2005). Estrogenicity, characterized as estradiol equivalents (EEq) using two different bioassays, was 20-54 ng EEq/L in the plant influent, but decreased to 5-19 ng EEq/L after advanced biological treatment. Tertiary treatment consisting of sand filtration, ozonation, activated carbon treatment, and ultraviolet disinfection further reduced estrogenicity to $<0.75$ ng EEq/L.

Changes in endocrine disrupting activity during secondary wastewater treatment was monitored using chemical analysis (GC-NCI-MS and HPLC-ELISA) and five different bioassays (Drewes et al., 2005). Steroidal hormones (E1, E2, E3, EE2, and testosterone), three surfactant metabolites, and BPA were analyzed in seven fullscale and two pilot-scale secondary WWTPs. Secondary treatment processes removed about $94 \%$ of estrogenic activity and $96 \%$ of the testosterone. Effluent estrogenicity was due mostly due to residual concentrations of E2 and E3.

Seventeen WWTPs across the countries of Norway, Sweden, Finland, The Netherlands, Belgium, Germany,
France, and Switzerland were sampled for E1, E2, EE2, and NP (Johnson et al., 2005). The highest estrogen levels (6.5 ng E2/L, 50.5 ng E1/L) were found from one WWTP which utilized primary treatment only. E2 (avg. 0.7-5.7 ng/L) was only detected in 6 of 16 treatment plants which utilized secondary treatment, while E1 was detected in 13 (median 3.0 $\mathrm{ng} / \mathrm{L}$ ) and EE2 was only found in two plants. NP was detected in all 14 where samples were taken (median 0.31 $\mathrm{g} / \mathrm{L})$. The authors noted that as the hydraulic and cell residence times increased, the effluent concentrations decreased.

Occurrence and Fate - Surface Water and Sediment. A wide range of estrogenic contaminants, including natural and synthetic hormones, phthalates, surfactants, and BPA, were detected at low levels in surface water, sediment, wastewater, and rainwater samples taken in The Netherlands (Vethaak et al., 2005). In rainwater, BPA, octylphenol, and nonylphenol ethoxylates were found at concentrations of as high as 57,280 , and $990 \mathrm{ng} / \mathrm{L}$, respectively. In surface waters, these substances were found at concentrations up to $1,000,6,300$, and $8,700 \mathrm{ng} / \mathrm{L}$, respectively, along with lower levels of hormones (generally $<8 \mathrm{ng} / \mathrm{L}$ ). Most estrogenic activity in surface water samples was from EE2 and other steroids.

Twenty-six EDCs were monitored at two sites along the Ebre River and an irrigation canal of the Ebre Delta in Catalonia, Spain (Brossa et. al., 2005). Concentrations ranged between 0.01 and $13 \mathrm{~g} / \mathrm{L}$ with phthalates and bis-(2ethylhexyl) adipate having levels of 0.05 to $13 \mathrm{~g} / \mathrm{L}$. Concentrations of estrogens, pesticides, and alkylphenols were found in water samples at levels of $0.1 \mathrm{~g} / \mathrm{L}$ or below. All surface waters from the Llobregat River in Catalonia, 
Spain sampled by Céspedes et al. (2005) had concentrations ranging from 0.06 to $37.3 \mathrm{~g} / \mathrm{L}$ of at least one endocrine disruptor. The alkyphenol compounds were detected between $0.1-37.7 \mathrm{~g} / \mathrm{L}$ in surface waters. Four sewage treatment plants (STP) removed $70-90 \%$ of the influent estrogenic activity and 83 to $97 \%$ of NP from influent wastewaters.

Over a period of 20 months, water samples from 10 Portuguese rivers were monitored for estrogenicity and estrogenic EDCs using the recombinant yeast assay (RYA) and chemical analyses (Quiros et al., 2005). Of the 183 samples taken, $74 \%$ showed no response with the RYA test, while about $17 \%$ of the samples showed weak estrogenicity $(<0.1 \mathrm{ng} \mathrm{EEq} / \mathrm{L})$ and about $9 \%$ had 0.1 to $1.7 \mathrm{ng} \mathrm{EEq} / \mathrm{L}$. Samples with significant estrogenic activity were generally from locations impacted by industrial activities. The most prevalent EDC was NPEO2, which was detected in all samples at concentrations up to $12.6 \mathrm{~g} / \mathrm{L}$; NP was also commonly detected, at concentrations as high as $25.5 \mathrm{~g} / \mathrm{L}$.

Extracts of marine sediments from Southern California had measurable levels of E1 (0.6 ng/g) and E2 (0.16-0.45 $\mathrm{ng} / \mathrm{g}$ ) as well as several alkylphenols and alkylphenol ethoxylates (Schlenk et al., 2005). Sediment samples from the Scheldt estuary, The Netherlands had estrogenic activity equivalent to $7.7 \mathrm{pmol} \mathrm{E2/g}$ dry weight (dw) as measured with the YES assay (Verslycke et al., 2005). Sediment estrogenicity was attributed to nonylphenol ethoxylates $(1,400$ $\mathrm{ng} / \mathrm{g} \mathrm{dw})$, nonylphenol (1,222 ng/g dw), and brominated flame retardants, including BDE-209 (240-1650 ng/g dw). Sediments from 83 remote European lakes were tested for estrogenic activity using the RYA (Garcia-Reyero et al., 2005). High estrogenic activities appeared mainly in recently-deposited sediments and were correlated to polycyclic aromatic hydrocarbon $(\mathrm{PAH})$ or organochlorine compound concentrations.

A cross-flow ultrafiltration system with 1-kDa regenerated cellulose ultrafiltration membrane was used to measure partitioning of EDCs (BPA, E1, E2, E3, EE2 and 16 -hydroxyestrone) between river colloids and the dissolved phase (Liu et al., 2005a). Partition coefficients normalized to colloidal organic carbon content $\left(\mathrm{K}_{\mathrm{coc}}\right)$ ranged from $8.85 \times 10^{3}$ to $4.87 \times 10^{4} \mathrm{~mL} / \mathrm{g}$. The findings indicated that these compounds have a higher affinity for colloidal material than for river sediments.

Drinking Water Treatment. Choi et. al (2005) studied the removal of three EDCs (amitrol, nonylphenol, and bisphenol-A) from water using adsorption GAC. The study indicated GAC adsorption was effective in removing EDCs with high $\mathrm{K}_{\mathrm{ow}}$ values and that coal-based virgin carbon was more effective than wood-based or coconut-based GACs in adsorbing nonylphenol and bisphenol-A. However, GAC adsorption was ineffective for removing amitrol.

Six EDCs (BPA, E1, E2, EE2, E3, and NP) tested by Deborde et al. (2005) can be effectively oxidized by ozone, although oxidation rates are much more rapid under basic conditions $(\mathrm{pH}>10)$ as compared to acidic conditions $(\mathrm{pH}<5)$. Second-order rate constants were reported for these compounds for a $\mathrm{pH}$ range of $2.5-10.5$ at $20^{\circ} \mathrm{C}$. At $\mathrm{pH} 7$ and $20^{\circ} \mathrm{C}$, oxidation of these compounds by ozone was much more rapid and effective than oxidation with chlorine.

\section{Endocrine Disrupting Compounds - Hormones}

Sampling and Extraction. Passive organic chemical integrative samplers (POCIS), using Oasis HLB and a mixture of Isolute ENV+ and Ambersorb 1500 as the sorbent phases, 
were used with the yeast estrogen screen (YES) and HPLC with triple quadrupole MS to monitor estrogen levels in Swiss rivers, lakes, and WWTP effluents (Vermeirssen et al., 2005). POCIS results correlated will with bioaccumulation of estrogens in caged brown trout, indicating that the POCIS can be used as an integrative sampling device to monitor potential biological effects.

Automated SPE method followed by HPLC/MS/MS was developed for analysis of E1, E2, and EE2 in environmental water samples (Zuehlke et al., 2005). To eliminate matrix interferences, SPE cartridges were washed with distilled water, methanol/water $(1: 1)$, acetone/water $(1: 2)$ and n-hexane after sample extraction and prior to elution with methanol. Raw wastewater samples required an additional cleanup procedure. Limits of quantification ranged from $1-2 \mathrm{ng} / \mathrm{L}$ in raw wastewater, $0.2-0.4 \mathrm{ng} / \mathrm{L}$ in treated wastewater, and 0.1 $0.2 \mathrm{ng} / \mathrm{L}$ in drinking water, surface water, and groundwater.

Fully automated in-tube SPME, used without other sample pretreatment, was developed for high throughput analysis of five estrogens (E1, E2, E3, EE2, and DES) in environmental water samples (Mitani et al., 2005). Sample

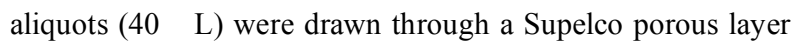
open tubular capillary column. Analytes sorbed to the inner surface of the capillary and were then desorbed into the mobile phase for analysis by HPLC/MS/MS. Detection limits ranged from $2.7-11.7 \mathrm{ng} / \mathrm{L}$. Using this method, effluent from a WWTP in Japan was found to have $35.7 \mathrm{ng}$ E3/L.

A hollow fiber membrane coated with dihydroxylated polymethylmethacrylate (DHPMM), a novel functional polymer sorbent, was used for microextraction of trace levels of natural and synthetic estrogens (E1, E2, E3 and DES) from water samples (Basheer et al., 2005a). After a 30-minute extraction time, analytes were ultrasonically desorbed into dichloromethane, derivatized with MSTFA, and analyzed by GC-MS in SIM mode. The limits of detection ranged from $0.03-0.8 \mathrm{ng} / \mathrm{L}$, and real sample matrices (tap water and water from a reservoir) had little effect on extraction efficiency.

A MIP was developed for preconcentrating E2 from aqueous samples by Bravo et al. (2005). The MIP was prepared using E2 as the template molecule. Polymer particles were packed into a capillary column as part of a flow injection system utilizing fluorescence detection. The system is capable of analyzing 10 samples per hour and has a detection limit of $1.12 \mathrm{~g} / \mathrm{L}$.

Analytical Methods. Prior to analysis by GC-MS, E1 and EE2 are often converted to silylated derivatives using BSTFA or MSTFA. In response to a report that BSTFA derivatives of EE2 can be converted to E1 derivatives, thereby confounding analytical results, Zuo and Zhang (2005) described a method of using BSTFA as a derivatizing agent with $1 \%$ trimethylchlorosilane (TMCS) as a catalyst for E1 and EE2 using pyridine as a solvent, which prevents conversion of the EE2 derivative. With a volume ratio of pyridine to BSTFA $+1 \%$ TMCS of greater than $1: 4$, no conversion of derivatives was observed.

Conjugated forms of estrogens, which are much less biologically active than estrogens in the free deconjugated state, are precursors to EDCs in wastewater collection and treatment systems. Reddy et al. (2005) describe a method for analysis of steroids and their conjugates in treated and untreated sewage using SPE with extensive clean-up and LC/MS/MS. Method detection limits for steroid conjugates in fortified reagent water ranged from 0.04 to $0.28 \mathrm{ng} / \mathrm{L}$. Analysis of influent and effluent samples from a New York 
WWTP revealed concentrations of estrone-3-sulfate at 34 $\mathrm{ng} / \mathrm{L}$ compared to the free form of estrone at $24 \mathrm{ng} / \mathrm{L}$ in influent wastewater. Gomes et al. (2005) developed a similar method for simultaneous determination of natural and synthetic estrogens and their conjugates in environmental water samples. The use of reverse phase SPE followed by LC/MS/MS optimized to minimize matrix interferences allowed direct determination of the free and conjugated estrogens. Limits of detection in raw sewage ranged from 1.8 ng EE2/L to $7.1 \mathrm{ng}$ E3-16 -glucuronide/L. Free and conjugated forms of estrogens were detected in untreated wastewater at concentrations approaching $70 \mathrm{ng} / \mathrm{L}$.

A LC-ESI-MS method was developed for analysis of estrogens (E1, E2, E3, and EE2) in water samples (Hu et al., 2005). Analytes were extracted from water samples using C18 SPE, cleaned up with Florisil and $\mathrm{NH}_{2}$ SPE cartridges, separated with a phenyl column, and detected with a single quadrupole MS. In river water, the limits of detection were estimated as $0.1 \mathrm{ng} / \mathrm{L}$ for E1, E2, and EE2, and as $0.2 \mathrm{ng} / \mathrm{L}$ for E3. Samples from an effluent-impacted river in Beijing, China had 1.1 ng E1/L.

A method was developed for determination of E1 and E2 in complex sediment samples (Reddy and Brownawell, 2005). Dry sediment was extracted with methanol in a heated ultrasonic bath, and extracts were subjected to a multi-step clean up procedure to reduce matrix interferences prior to analysis by HPLC-TOF MS. The method detection limits for $\mathrm{E} 1$ and E2 were 0.03 and $0.04 \mathrm{ng} / \mathrm{g}$, respectively. The method was applied to analysis of sediments from Jamaica Bay, New York, which had E1 concentrations ranging from $0.07-2.52$ $\mathrm{ng} / \mathrm{g}$ and $\mathrm{E} 2$ concentrations ranging from $0.05-0.53 \mathrm{ng} / \mathrm{g}$.
Occurrence and Fate - Wastewater Treatment. Eighteen municipal STPs in Canada having a variety of processes were evaluated for 17 -estradiol (E2) and estrone (E1) removal (Servos et al., 2005). Influent and effluent concentrations of E2 ranged from $2.4-26 \mathrm{ng} / \mathrm{L}$ and $0.2-14.7$ $\mathrm{ng} / \mathrm{L}$, respectively, and influent and effluent concentrations of E1 were between 19 and $78 \mathrm{ng} / \mathrm{L}$ and 1 and $96 \mathrm{ng} / \mathrm{L}$, respectivley. STPs with longer solids or hydraulic retention times had higher removals and greater reliability. Braga et al. (2005c) studied removals of E1, E2, and, EE2 in two Australian wastewater treatment plants: an advanced sewage treatment plant (STP) and an enhanced primary STP. Average influent concentration ranges for the two plants were 53-55 ng E1/L, 12-22 ng E2/L, and $<1$ ng EE2/L. The advanced STP removed up to $85 \%$ and $96 \%$ of E1 and E2, respectively, through the activated sludge process, and reverse osmosis further reduced effluent estrogen concentrations to below $0.1 \mathrm{ng} / \mathrm{L}$. The enhanced primary STP removed only $14 \%$ and $5 \%$ of the influent E1 and E2, respectively. The percentages of effluent E1, E2, and EE2 sorbed to solid particles in wastewater effluent were estimated as $24 \%, 43 \%$, and $100 \%$, respectively (Braga et al., 2005a). The distribution coefficients $\left(\mathrm{K}_{\mathrm{d}}\right)$ for $\mathrm{E} 1$, E2, and EE2 between activated sludge and water are $402 \pm 126 \mathrm{~L} / \mathrm{kg}, 476 \pm 192 \mathrm{~L} / \mathrm{kg}$ and $584 \pm 136 \mathrm{~L} / \mathrm{kg}$, respectively (Andersen et al. 2005). In many cases, removal of these compounds by sorption to waste activated sludge is a minor removal mechanism.

Complete removal of testosterone, androstenedione, progesterone, and estradiol was reported in biological wastewater treatment (Suidan et al., 2005). Estrone, estriol, and ethinylestradiol were removed at 95, 99, and $83 \%$, respectively. Li et al. (2005) studied aerobic biodegradation 
of E2 by activated sludge at an activated sludge WWTP in Gifu, Japan. With a mixed liquor volatile suspended solids concentration of $1750 \mathrm{mg} / \mathrm{L}, 99.2 \%$ of an initial $30 \mathrm{~g} \mathrm{E} / \mathrm{L}$ was degraded in 1.5 hours at $20^{\circ} \mathrm{C}$.

An engineered treatment wetland receiving flows from the Santa Ana River,California was evaluated to determine the fate of estrogenic hormones (Gray and Sedlak, 2005). The wetland cell tested contained primarily cattails and bulrushes, had a total volume of $368 \mathrm{~m}^{3}$ and a hydraulic retention time of 84 h. Initial E2 and EE2 concentrations of 2.25 and 2.40 $\mathrm{mg} / \mathrm{L}$, respectively, were reduced by $36 \%$ and $41 \%$, respectively.

Occurrence and Fate - Surface Water and Sediment. Conjugated and unconjugated steroidal hormones (E1, E2, E3, EE2, and four others) were monitored in the effluent of a French wastewater treatment plant and the receiving stream (Labadie and Budzinski, 2005). Only free steroids (E1, E2, and E3) were detected in the effluent, with E1 being the most significant (concentrations up to $71.4 \mathrm{ng} / \mathrm{L}$ ), and estrone was also detected in the river up to $10 \mathrm{~km}$ downstream of the discharge.

Braga et al. (2005b) determined that the concentrations of estrogens in the marine sediment $7 \mathrm{~km}$ from the deep ocean sewage outfall near Sydney, Australia were generally higher than the sediment adjacent to the outfall. Concentrations ranged from $0.16-1.17 \mathrm{ng} / \mathrm{g}, 0.22-2.48 \mathrm{ng} / \mathrm{g}$, and $<0.05-$ $0.5 \mathrm{ng} / \mathrm{g}$ for E1, E2, and EE2, respectively. Estrogens sorbed to particles in the wastewater effluent apparently aggregated and settled to the seafloor after contact with higher ionic strength seawater.

Occurrence and Fate - Sludges, Soils, and Groundwater. Column and batch experiments were conducted to determine the sorption, mobility and transformation of E1 and E2 (Casey et al., 2005). Sorption equilibrium was found to occur in $<24$ hours, and the 48 -hour $\log \mathrm{K}_{\mathrm{oc}}$ values of E1 and E2 were determined to be 2.99 and 2.94 , respectively.

Degradation of water-soluble E2 and testosterone over 133 and 139 days in composted chicken manure followed first order kinetics with $\mathrm{k}=0.010 / \mathrm{d}$ for $\mathrm{E} 2$ and $\mathrm{k}=0.015 / \mathrm{d}$ for testosterone (Hakk et al., 2005). Since both contaminants could be detected at the conclusion of composting, the authors concluded that composting is an effective means for reducing, but not eliminating water soluble these hormones. The addition of swine manure slurry increased the transformation rates of testosterone and E2 in organic-amended soils (Jacobsen et al., 2005). Microbes in the manure slurry were responsible for the parent compound degradation, while mineralization of the hormones required soil microorganisms.

Testosterone dissipation and degradation was tested on different agricultural soils at different moisture contents (1.7$39 \%)$ and temperatures $\left(4-30^{\circ} \mathrm{C}\right)$ to determine if the androgenic substances from intensive livestock operations pose a threat to surface and groundwater (Lorenzen et al., 2005). Testosterone and its byproducts rapidly dissipated in soils with moisture contents and temperatures comparable to a temperate growing season. Degradation of $50 \%$ of the compound occurred within 8.5-21 h.

Drinking Water Treatment. The removal of E1 and E2 from water by adsorbents including GAC, chitin, chitosan, ion exchange resin, and carbonaceous adsorbent prepared from industrial waste was examined by Zhang and Zhou (2005). Adsorption kinetics were compound dependent, and sorption equilibrium for E2 varied from 2 hours for the waste-derived 
adsorbent to 125 hours for GAC. GAC was very effective in removing these compounds from water, although GAC adsorption capacity was reduced by the presence of surfactants and humic acid.

\section{Endocrine Disrupting Compounds - Surfactants, Plasticizers, and Other}

Analytical Methods. A microwave-assisted extraction (MAE) method was developed for simultaneous extraction of phthalate esters, nonylphenols, and polychlorinated biphenyls, and polycyclic aromatic hydrocarbons in sediments (Bartolomé et al., 2005). Analytes were extracted from sediments into acetone at 21 psi under microwave irradiation, and extracts were cleaned up using SPE with Florisil cartridges to eliminate interferences prior to analysis by GCMS. Limits of detection were $0.5-22 \mathrm{ng}$ for differnet phthalate esters and $100 \mathrm{ng}$ for nonylphenols.

A method utilizing polymer coated hollow fiber membrane extraction (PC-HFME) for extraction of alkylphenols and BPA was developed by Basheer et al. (2005b). The sorbent for this microextraction method was a novel polymer, hydroxylated polymethacrylate, coated on porous polysulfone. After extraction and derivatization with BSTFA, analytes were quantified by GC-MS. The method required a shorter extraction time and provided lower detection limits $(0.07-2.34 \mathrm{ng} / \mathrm{L})$ than extraction by SPME.

An optical immunosensor utilizing aminodextran derivatives of BPA bound to a transducer was developed for BPA analysis in river water (Rodriguez-Mozaz et al., 2005). Upon exposure to BPA, the sensor produces measurable fluorescence with a reported BPA detection limit of $14 \mathrm{ng} / \mathrm{L}$. The sensor surface can be regenerated, allowing multiple measurements. MIPs prepared with 4,4'-methylenebisphenol (MBP; a structural analog of BPA) and surface modified to eliminate sample interferences were used for extraction of BPA from environmental water samples (Watabe et al., 2005). By using MBP, potential leakage of BPA during analyte extraction was avoided. When coupled with HPLC with electrochemical detection, this extraction method provided a detection limit of $0.36 \mathrm{ng} / \mathrm{L}$ from a $50 \mathrm{~mL}$ water sample.

Extraction of six phthalates (including dimethylphthalate, diethylphthalate, DBP, and DEHP) from water by direct SPME prior to GC-MS analysis was optimized by Polo et al. (2005). Optimal extraction conditions utilized an extraction temperature of $100^{\circ} \mathrm{C}$ and a PDMS-DVB fiber for 20 minutes. Limits of detection ranged from $2-103 \mathrm{ng} / \mathrm{L}$. These same analytes were simultaneously analyzed in lyophilized sewage sludge and soil (Sablayrolles et al., 2005). $n$-Hexane was used for the 45minute extraction, and extracts were cleaned up with a Florisil SPE cartridge prior to analysis by GC-MS. The method allows detection of these analytes at concentrations as low as $10 \mathrm{~g} / \mathrm{kg}$ dry matter.

Micellar electrokinetic chromatography (MEKC) was used to separate multiple phthalates in Soxhlet extracts of soil samples (Guo et al., 2005). The micellar buffer used for MEKC was $100 \mathrm{mM}$ sodium cholate, $50 \mathrm{mM}$ borate, and 15\% methanol at $\mathrm{pH} \mathrm{8.5,} \mathrm{and} \mathrm{UV} \mathrm{detection} \mathrm{was} \mathrm{at} 214 \mathrm{~nm}$. The detection limits for DEHP and DnOP were 0.054 and 0.063 $\mathrm{mg} / \mathrm{kg}$, respectively.

BPA and several chlorinated and brominated BPA analogues were simultaneously analyzed in sediment and sludge samples (Chu et al., 2005). Analytes were Soxhlet 
extracted, fractionated into neutral and phenolic fractions, and enriched and cleaned up with sequential SPE steps prior to analysis by LC/MS/MS with negative ESI. Method limits of quantification were reported as $0.02-0.15 \mathrm{ng} / \mathrm{g}$ dry weight.

An SPE method utilizing sodium dodecyl sulfate (SDS) surfactant micelles sorbed to alumina was used to extract and concentrate BPA and bisphenol-F (BPF) in environmental water samples (Moral et al., 2005). Optimal extraction utilized about $85 \mathrm{mg}$ SDS/g alumina, with tetrabutylammonium chloride (TBAC) added to the sample to modify the SDS admicelles. BPA and BPF were eluted with methanol prior to analysis by LC with fluorimetric detection (278 nm excitation; $306 \mathrm{~nm}$ emission). Levels of detection were 10 and $15 \mathrm{ng} / \mathrm{L}$ for $\mathrm{BPF}$ and $\mathrm{BPA}$, respectively. A similar extraction method was utilized for determining alkylphenol ethoxylates and akyl ethoxylates from water samples (Cantero et al., 2005). The method required about 20-25 mg SDS/g alumina, and produced analyte recoveries of $91-98 \%$ from wastewater influent, effluent, and river water samples. Analytes were quantified with HPLC-APCI with ion-trap MS, yielding detection limits of 14-111 ng/L, 10-40 $\mathrm{ng} / \mathrm{L}$, and 4-35 ng/L for wastewater influent, wastewater effluent, and river water samples, respectively.

Stir-bar sorptive extraction (SBSE) was combined with thermal desorption (TD) and in-tube silylation for analysis of alkylphenols (AP) in water samples (Kawaguchi et al., 2005). Analytes were extracted from $2.0 \mathrm{~mL}$ water samples with a PDMS-coated stir bar over 60 minutes, then thermally desorbed and derivatized with BSTFA prior to GC-MS analysis. Limits of quantification ranged from 1-50 ng/L for 10 APs that were tested. The method was applied to analysis of river water samples, which had 12.6-18.2 ng/L OP and
55.1-59.7 ng/L NP. SPE was coupled with derivatization for analysis of 4-alkylphenols (Kojima et al., 2005). Aqueous samples were extracted using C18 SPE cartridges conditioned with an ion-pair reagent (tetra- $n$-hexylammonium bromide). Analytes were eluted and derivatized with a solution of $0.1 \%$ pentafluoropyridine in acetone prior to GC-MS analysis. Analysis of 20-mL water samples provided detection limits of $76 \mathrm{ng} / \mathrm{L}$ for NP and 5.2-8.9 ng/L for other 4-alkylphenols (C4C8).

MAE combined with HPLC separation and fluorescence detection (excitation at $222 \mathrm{~nm}$; emission at $305 \mathrm{~nm}$ ) was used for analysis of NP and NPnEOs in sewage sludge (Fountoulakis et al., 2005). Analysis of most samples required no further extract cleanup, and the method had limits of detection (signal/noise ratio of 3) of 2.86 and $1.82 \mathrm{~g} / \mathrm{g}$ dry weight for NP and NPEO, respectively. A relatively fast and simple method to simultaneously extract 4-nonylphenols and phthalates in digested sewage sludge, soil, and sludgeamended soil was developed (Gibson et al., 2005). Analytes were Soxhlet-extracted in the presence of copper filings, and extracts were cleaned up with a cyanopropyl SPE cartridge prior to GC-MS analysis. The limits of detection were 10 $\mathrm{g} / \mathrm{kg}$ for NPs and $0.1-5 \mathrm{~g} / \mathrm{kg}$ for the phthalates.

A two-dimensional GC method $(\mathrm{GC} \times \mathrm{GC})$ with $\mathrm{MS}$ detection was used for separating and quantifying nonylphenol isomers in technical mixtures and environmental samples (Ieda et al., 2005). For analysis of $60-\mathrm{mL}$ water samples, SBSE was followed by thermal desorption and GC $\times$ GC using a DB-5 and DB-WAX capillary columns. The limits of detection ranged from $0.19-0.7 \mathrm{ng} / \mathrm{L}$.

Occurrence and Fate - Wastewater Treatment Systems. In batch tests with unacclimated activated sludge, a 
commercial NPEO mixture (Igepal CO520) was biodegraded by an intracellular enzyme process (Langford et al., 2005a). Long chain NPEOs were degraded to short chain oligomers and NP over 5 hours without any acclimation period, and compound distribution between the sorbed and dissolved phases was dependent on hydrophobicity of each compound. Phthalates are removed to different extents in trickling filters (Oliver et al., 2005). Removals of diethyl phthalate at an influent concentration of $25.0 \mathrm{~g} / \mathrm{L}$ ranged from $94-99 \%$, whereas di(2-ethylhexyl) phthalate (DEHP) removals were much lower $(<1-44 \%)$ at a similar influent concentration $(23.6$ g/L). Partitioning of hydrophobic NPEOs and PBDEs to activated sludge solids is also an important removal mechanism (Langford et al., 2005b). In general, compounds with higher $\log \mathrm{K}_{\mathrm{ow}}$ are removed to a greater degree by sorption, and sorption increased as biomass concentration increased with solids retention time.

UV photolysis at $254 \mathrm{~nm}$, as commonly applied for disinfection, may effectively reduce concentrations of di- $n$ butyl phthalate (DBP) in wastewater effluent or drinking water (Lau et al., 2005). DBP was initially degraded under first order kinetics, with the rate constant increasing with $\mathrm{pH}$, presumably due to the additional degradation mechanism of base catalyzed hydrolysis. Although reaction mechanisms varied with $\mathrm{pH}$, a major end product was phthalic acid. Other substituted phenols and phenolic EDCs may be effectively oxidized during water or wastewater treatment with ferrate (Fe(IV)) (Lee et al., 2005b). Ferrate oxidation of EE2, E2, and BPA was well described by second order kinetics, with apparent second order rate constants ranging from $640-770$ $\mathrm{L} / \mathrm{mol} \cdot \mathrm{s}$ at $\mathrm{pH} 7$.

\section{Occurrence and Fate - Surface Water and Sediment.}

Under aerobic conditions in river water, an initial BPA concentration of $1000 \mathrm{~g} / \mathrm{L}$ was biodegraded to below detection limits within 7 days (Kang and Kondo, 2005). Degradation was much slower in aerobic seawater, with no degradation until approximately 30 days. BPA can be biodegraded by the green alga, Chlorella fusca (Hirooka et al., 2005). In 169-hour batch tests with C. fusca continuously illuminated at $18 \mathrm{~W} / \mathrm{m}^{2}$, initial BPA concentrations of 10-80 M were completely biodegraded. Although one degradate (monohydroxy-BPA) was detected, estrogenicity of the culture solutions determined with a recombinant yeast assay decreased as BPA disappeared.

Phthalate ester isomers (dimethyl isophthalate and dimethyl phthalate) were used as a sole carbon and energy source during biodegradation by bacterial consortia enriched from mangrove sediments (Gu et al., 2005). Isolated species partially degraded both compounds, producing persistent metabolites that were degraded by the consortium. Three phthalate esters were readily degraded under anaerobic conditions when incubated $\left(\mathrm{pH} 7,30^{\circ} \mathrm{C}\right)$ with river sediment from Taiwan (Chang et al., 2005c). Diethyl phthalate, DBP, and DEHP had half-lives of 15.4, 9.4, and $25.7 \mathrm{~d}$ in anaerobic microcosms with $45 \mathrm{~mL}$ liquid and $5 \mathrm{~g}$ sediment. Addition of nonionic surfactants also improved degradation rates, presumably by enhancing contaminant bioavailability. $o$ Phthalate is anaerobically biodegraded in a $\mathrm{CO}_{2} / \mathrm{H}_{2}$ atmosphere (Liu et al., 2005b,c). Over $52 \mathrm{~d}, 9.4 \mathrm{mg} / \mathrm{L}$ of $o$ phthalate was reduced to $1.3 \mathrm{mg} / \mathrm{L}$, with an initial $14-\mathrm{d}$ lag period in batch tests with no additional carbon source. Increasing $\mathrm{H}_{2}$ levels in the reactor headspace resulted in faster 
$o$-phthalate biodegradation rates but did not shorten the initial lag period.

With an organic carbon source, NPEOs are rapidly converted by aerobic biodegradation to corresponding nonylphenol polyethoxy carboxylates (NPnEC), presumably by oxidation of the terminal alcohol group (Hayashi et al., 2005). Without organic matter, NP10EO was converted mainly to NP2EO and NP3EO. Different forms of organic carbon that may exist in surface waters significantly affect the partitioning and bioavailability of nonylphenol (Burgess et al., 2005). Partitioning coefficients ranged from $21.3 \mathrm{~L} / \mathrm{kg}$ for cellulose to $9770 \mathrm{~L} / \mathrm{kg}$ for humic acid. These differences in partitioning had a direct influence on bioavailability.

Occurrence and Fate - Sludges, Soil, and Groundwater. Soxhlet extraction followed by HRGC-MS was used to monitor the change in DEHP concentrations throughout different sludge treatment processes and during incubation of sludge/soil mixtures (Bagó et al., 2005). DEHP was found at $180-267$ ppm dry matter in sewage sludge, and concentrations decreased during aerobic composting to $38-43$ ppm. Over 9 months in sludge/soil mixtures, DEHP concentrations decreased by $59-94 \%$; no correlations were observed between soil types, environmental samples, and phthalate degradation.

DBP and DEHP were completely degraded within $28 \mathrm{~d}$ in anaerobic microcosms $\left(\mathrm{pH} 7,30^{\circ} \mathrm{C}\right)$ with $5 \mathrm{~g} / \mathrm{L}$ of petrochemical or wastewater sludges (Chang et al., 2005d). In the petrochemical sludge, DBP and DEHP had half-lives of 1.2 and $6.2 \mathrm{~d}$, respectively, in tests with the contaminants as the sole carbon source. Similar tests with NP at an initial concentration of $5 \mathrm{mg} / \mathrm{L}$ yielded NP half-lives of 23.9 and $36.5 \mathrm{~d}$ for sewage sludge and petrochemical sludge, respectively (Chang et al., 2005a). NP degradation rates increased with temperature, with the fastest degradation occurring at the highest temperature $\left(50^{\circ} \mathrm{C}\right)$ tested. Under aerobic conditions, NP and NP1EO were both degraded in sewage sludge when present as the sole carbon source (Chang et al., 2005b). At an initial concentration of $5 \mathrm{mg} / \mathrm{L}$, NP1EO was completely degraded over $35 \mathrm{~d}$, with corresponding production of NP, which was not persistent. Addition of yeast extract and a nonionic surfactant improved degradation rates.

DEHP in surface soil at $5.51 \mathrm{mg} / \mathrm{kg}$ was bioremediated in slurry phase and solid phase reactors (Di Gennaro et al., 2005). Under idealized conditions (supplemental nitrogen and phosphorus; inoculation with a DEHP-degrading bacterium), first-order degradation rate constants were 2.03 and $0.078 \mathrm{~d}^{-1}$ for slurry phase and solid phase bioremediation systems, respectively.

The dominant isomer in technical NP mixtures, 353nonylphenol (4-(3,5-dimethyl-3-heptyl)phenol), is readily sorbed in soils and sludges, with $\log \mathrm{K}_{\mathrm{oc}}$ values of 3.8-5.75 (Telscher et al., 2005). In long term (135 d) aerobic incubation with soil/sludge mixtures, up to $6 \%$ of the parent compound was volatilized and up to $30 \%$ was mineralized. A less polar metabolite, identified as 4-(3,5-dimethyl-3-heptyl)2-nitrophenol, was also produced, presumably via biotransformation.

Drinking Water Treatment. BPA is effectively removed from water by adsorption to activated carbon (Bautista-Toledo et al., 2005). Three carbons were tested, and each had relatively high BPA adsorption capacities (129.6 $263.1 \mathrm{mg} / \mathrm{g}$ determined by Langmuir isotherm analysis). BPA adsorption improved with increasing ionic strength and at $\mathrm{pH}<8$, where BPA exists in solution in its molecular form. 


\section{Brominated Flame Retardants}

Analysis. A relative retention time database for 126 PBDE congeners eluting on seven different capillary GC columns was presented by Korytár et al. (2005), with the goal of allowing design of analytical protocols for either comprehensive or congener-specific BDE analysis. All columns were $30 \mathrm{~m} \times 0.25 \mathrm{~mm}$ with $0.25 \mathrm{~m}$ film thickness and were tested under similar conditions. A DB-XLB column was found to be the most efficient column for separation of congeners, based on the minimal number of co-eluting compounds, although a DB-1 column was nearly as efficient, but with less degradation of hepta- and higher brominated PBDE congeners.

Pepich et al. (2005) developed a method for the U.S. Environmental Protection Agency (EPA) that allowed analysis of a wide range of emerging contaminants in drinking waters, including 4 PBDE congeners (BDE-47, BDE-99, BDE-100, and BDE-153) along with 21 other analytes. The method specifies preservation of samples to $\mathrm{pH}$ 3.8 with citric acid, addition of ascorbic acid to remove free available chlorine, and storage in amber glass bottles to minimize analyte degradation prior to analysis. Analytes are extracted using a SDVB disk, eluted with ethyl acetate and methylene chloride, and analyzed by GC-MS in full scan mode with internal standards for calibration. Detection limits for 1-L samples ranged from $0.025-0.14 \mu \mathrm{g} / \mathrm{L}$.

Atmospheric pressure photo ionization (APPI) was utilized as an ionization technique for LC/MS analysis of aromatic BFRs (PBDEs and TBBPA) and their degradation products that cannot be easily analyzed using GC-MS (Debrauwer et al., 2005). Although the method appeared to be applicable to qualitative analysis and structural identification of PBDE isomers and their degradates, simultaneous quantitative analysis of multiple analytes cannot yet be accomplished due to solvent interferences with APPI, unless multiple internal standards are utilized.

A non-aqueous capillary electrophoresis (NACE) method utilizing methanol as the solvent and photodiode array ultraviolet detection was developed for analysis of TBBPA and other phenolic compounds in environmental water samples (Blanco et al., 2005b). The method had an LOQ of 3 $\mathrm{g} / \mathrm{L}$ for TBBPA in wastewater using a large volume sample stacking injection method that improved concentration of analytes. In comparison to aqueous capillary electrophoresis, the NACE method eliminated matrix interferences more effectively, provided higher analyte concentration factors, and had lower levels of quantification (Blanco et al., 2005a).

\section{Occurrence and Fate - Surface Water and}

Sediment. PBDE concentrations in sediments of the Great Lakes were explored in several studies. PBDEs were evaluated in dated sediment cores from Lakes Michigan and Erie (Zhu and Hites, 2005). Total PBDE congeners were comprised of 95 to $99 \%$ BDE-209. Surficial sediment BDE209 concentrations were $315 \mathrm{ng} / \mathrm{g}$ and $39 \mathrm{ng} / \mathrm{g}$ dry weight for Lakes Michigan and Erie, respectively. The BDE-209 concentration was found to have a doubling time of about 7.5 y for Lake Michigan until 1980 where it leveled off and 5.3 y for Lake Erie. The total burden for PBDEs, including BDE209, were determined to be 110 metric tons for Lake Michigan and 10 metric tons for Lake Erie.

Results on the spatial distribution and sources of PBDEs in the sediment of Lakes Michigan and Huron were presented by Song et al. (2005b). Concentrations in the 
surficial sediments of Lakes Michigan and Huron, for nine trithrough hepta-BDE congeners, were found to be a maximum of $4 \mathrm{ng} / \mathrm{g}$ and $1.9 \mathrm{ng} / \mathrm{g}$ dry weight, respectively. On a mass basis, BDE-209 was found in the highest concentration of the total PBDEs in both Lakes Michigan and Huron with respectively making up approximately $96 \%$ and $91 \%$ of the total PBDEs. PBDE found away from the shores was due to air plumes from urbanized regions located within the proximity and upwind from the lakes. Song et al. (2005a) analyzed Lakes Ontario and Erie for 10 PBDE congeners and 39 polychlorianted biphenyls (PCB). PBDE concentrations and fluxes at present time of the sediment surface were found to have significantly increased at a maximum for Lake Ontario at $242 \mathrm{ng} / \mathrm{g}$ and $195 \mathrm{pg} / \mathrm{cm}^{2}$-yr, respectively, and for Lake Erie 55, ng/g and 314 pg/ $\mathrm{cm}^{2}$-yr, respectively. BDE-209 was found to make up $96 \%$ of the total PBDEs in Lake Ontario and $91 \%$ in Lake Erie. Concentrations in Lakes Ontario and Erie of nine tri- through hepta-BDE congeners were sampled at a maximum of $6.33 \mathrm{ng} / \mathrm{g}$ and $1.95 \mathrm{ng} / \mathrm{g}$ dry weight, respectively.

Two previously undetected brominated flame retardants, 1,2-bis(2,4,6-tribromophenoxy)ethane (TBE) and pentabromoethylbenzene (PEB), were identified in several particle phase atmospheric samples taken from several U.S. locations and a sediment sample from Lake Michigan (Hoh et al., 2005). In the sediment core, TBE was found at concentrations ranging from about $0.2-8 \mathrm{ng} / \mathrm{g}$ dry weight in sediment deposited between 1973 and 1993, but PEB and its byproducts were not detected in the same sediment core.

Oros et al. (2005) studied the levels and distribution of PBDEs in water and surface sediments from the San Francisco Estuary. The total PBDE concentrations in water samples ranged from 3 to $513 \mathrm{pg} / \mathrm{L}$, with the highest ranges in the Lower South Bay $(103-513 \mathrm{pg} / \mathrm{L})$ and the lowest ranges in the northern reaches of the Estuary (3-43 pg/L). The study showed that the PBDEs were predominately partitioned to filterable suspended particulate matter fraction.

PBDEs were measured in 15 sediment samples taken from four locations along the coast of Spain (Eljarrat et al., 2005). PBDE congeners were extracted from sediment by selective pressurized liquid extraction (SPLE) and analyzed by GC-NCI-MS using PCB-209 as an internal standard. Of the 40 PBDE congeners analyzed, twelve were detected, with two congeners (BDE-47 and BDE-209) detected in all samples. Total PBDE concentrations ranged from 2.7 to 134 ng/g dry weight, with highest concentrations in sediment samples from the mouth of the Llobregat River near Barcelona.

Mai et al. (2005) monitored spatial and temporal distributions of PBDEs in sediments of the Pearl River Delta in southern China and the adjacent South China Sea. Sixty-six surface sediment samples were taken and tested for BDE-209 and total BDEs (BDE-28, -47, -66, -100, -99, -154, - 153, and -138 ) and concentration ranges were determined to be 0.4 to $7340 \mathrm{ng} / \mathrm{g}$ (average of $9.9 \mathrm{ng} / \mathrm{g}$ ) and 0.04 to $94.7 \mathrm{ng} / \mathrm{g}$ (average $465 \mathrm{ng} / \mathrm{g}$ ), respectively. BDE-209 was dominant in the test areas, with 73 to $99.7 \%$ of the total PDBEs consisting of BDE-209. Two core samples were taken to examine the temporal distribution and the cores showed that the deeper layers of sediment had greater amounts of total PBDEs (1.2 $7.0 \mathrm{ng} / \mathrm{g})$ than the upper sediment layers $(0.07-5.8 \mathrm{ng} / \mathrm{g})$.

Photodegradation of five individual PBDE congeners and a technical mixture of five PBDEs was assessed by Sánchez-Prado et al. (2005a,b). Analytes were 
sorbed to polydimethylsiloxane (PDMS) SPME fibers (30 min of headspace-SPME extraction at $100^{\circ} \mathrm{C}$ ), the sorbed contaminants were irradiated on the fiber with ultraviolet light for periods of 2-60 min followed by GC-MS analysis, and degradation kinetics and byproducts were determined. In the study of individual PBDEs (Sánchez-Prado et al., 2005b), byproducts were tentatively identified and were found to be similar to compounds formed by direct photolysis in aqueous solution, indicating that the photo-SPME method provides comparable results to extraction from solution after irradiation. In the study a technical mixture of five PBDE congeners (Sánchez-Prado et al., 2005a), 21 different degradation products were detected. Reductive debromination is the likely mechanism for breakdown of the parent PBDEs, and degradation followed first order kinetics with reaction rates increasing with degree of bromination.

Occurrence and Fate - Sludge and Soil. Common polybrominated diphenyl ethers (PBDEs) were measured in soils and sediments near an electronic waste recycling facility in China (Wang et al., 2005). Soxhlet extraction and GC-MS were used to detect PBDEs in the range of $0.26-824 \mathrm{ng} / \mathrm{g}$ (dry weight). Uunsafe handling of electronics wastes by dismantling, acid treatment, and open burning have resulted in significant contamination that has migrated to the nearby river system. PBDEs were detected in soils in Sweden, with sewage-amended soils having 2-13 times higher BDE concentrations than non-amended soil (Sellstrom et al., 2005). BDE-209 and other higher

\section{References}

Aga, D.S., O'Connor, S., Ensley, S., Payero, J.O., Snow, D., and Tarkalson, D. (2005) Determination of the persistence of tetracycline antibiotics and their degradates in manure-amended brominated PBDEs are bioavailable and accumulated in earthworm populations (total PBDE concentrations in earthworms of 3.1 to $38,000 \mathrm{ng} / \mathrm{g}$ lipid weight).

$$
\text { Gerecke et al. (2005) studied BDE-209 }
$$

transformation by mesophilic anaerobic digester sludge over a period of 238 days. The BDE-209 concentrations decreased by $15-30 \%$ and followed pseudo-first-order degradation kinetics. BDE-207, BDE-208, and several octabromodiphenyl ether congeners were formed. Loss of $\operatorname{HBCD}\left(\mathrm{C}_{12} \mathrm{H}_{18} \mathrm{Br}_{6}\right)$ from soil and sediment was monitored by HPLC/MS in 4month aerobic and anaerobic microcosm experiments (Davis et al., 2005). HBCD was transformed in all biotic samples, and half-lives under anaerobic conditions (ranging from 1.1$6.9 \mathrm{~d})$ were much shorter than those for aerobic conditions (11-63 d) for similar soil or sediment. Although some loss of HBCD was observed in abiotic controls, biotransformation clearly was an important removal mechanism in biotic microcosms.

Tribromoneopentyl-alcohol (TBNPA) is an intermediate for BFRs, and is used as a reactive flame retardant in polyurethanes (Ezra et al., 2005). It is also present as a semivolatile contaminant in the vadose zone beneath an industrial complex in the northern Negev desert, Israel. Ezra et al. found that at $\mathrm{pH} 7-8$, TBNPA sequentially releases bromide as it undergoes decomposition to several degradates. The authors predicted that TBNPA would persist in the subsurface long after source elimination, with a half-life of about $100 \mathrm{y}$.

soil using enzyme-linked immunosorbent assay and liquid chromatography-mass spectrometry. J. Agric. Food Chem., 53, $7165-7171$ 
Agüera, A., Pérez Estrada, L.A., Ferrer, I., Thurman, E.M., Malato, S., and Fernandez-Alba, A.R. (2005) Application of time-offlight mass spectrometry to the analysis of phototransformation products of diclofenac in water under natural sunlight. J. Mass Spectrom., 40, 908-915.

Alvarez, D.A., Stackelberg, P.E., Petty, J.D., Huckins, J.N., Furlong, E.T., Zaugg, S.D., and Meyer, M.T. (2005) Comparison of a novel passive sampler to standard water-column sampling for organic contaminants associated with wastewater effluents entering a New Jersey stream. Chemosphere, 61, 610-622.

Andersen, H.R., Hansen, M., Kjølholt, J., Stuer-Lauridsen, F., Ternes, T., and Halling-Sørensen, B. (2005) Assessment of the importance of sorption for steroid estrogens removal during activated sludge treatment. Chemosphere, 61, 139-146.

Bagó, B., Martín, Y., Mejía, G., Broto-Puig, F., Díaz-Ferrero, J., Agut, M., and Comellas, L. (2005) Di-(2-ethylhexyl)phthalate in sewage sludge and post-treated sludge: Quantitative determination by HRGC-MS and mass spectral characterization. Chemosphere, 59, 1191-1195.

Balmer, M.E., Buser, H.R., Muller, M.D., and Poiger, T. (2005) Occurrence of some organic UV filters in wastewater, in surface waters, and in fish from Swiss lakes. Environ. Sci. Technol., 39, 953-962.

Barcelo, D. (2005) LC-tandem MS. TRAC-Trends Anal. Chem., 24, $564-565$.

Bartolomé, L., Cortazar, E., Raposo, J.C., Usobiaga, A., Zuloaga, O., Etxebarria, N., and Fernández, L.A. (2005) Simultaneous microwave-assisted extraction of polycyclic aromatic hydrocarbons, polychlorinated biphenyls, phthalate esters and nonylphenols in sediments. J. Chrom. A, 1068, 229-236.

Basheer, C., Jayaraman, A., Kee, M.K., Valiyaveettil, S., and Lee, H.K. (2005a) Polymer-coated hollow-fiber microextraction of estrogens in water samples with analysis by gas chromatography-mass spectrometry. J. Chrom. A, 1100, 137143.
Basheer, C., Parthiban, A., Jayaraman, A., Lee, H.K., and Valiyaveettil, S. (2005b) Determination of alkylphenols and bisphenol-A - A comparative investigation of functional polymer-coated membrane microextraction and solid-phase microextraction techniques. J. Chrom. A, 1087, 274-282.

Batt, A.L. and Aga, D.S. (2005) Simultaneous analysis of multiple classes of antibiotics by ion trap LC/MS/MS for assessing surface water and groundwater contamination. Anal. Chem., 77, 2940-2947.

Bautista-Toledo, I., Ferro-Garcia, M.A., Rivera-Utrilla, J., MorenoCastilla, C., and Fernandez, F.J.V. (2005) Bisphenol A removal from water by activated carbon. Effects of carbon characteristics and solution chemistry. Environ. Sci. Technol., 39, 6246-6250.

Beck, I.-C., Bruhn, R., Gandrass, J., and Ruck, W. (2005) Liquid chromatography-tandem mass spectrometry analysis of estrogenic compounds in coastal surface water of the Baltic Sea. J. Chrom. A, 1090, 98-106.

Benito-Peña, E., Moreno-Bondi, M.C., Orellana, G., Maquieira, K., and Van Amerongen, A. (2005) Development of a novel and automated fluorescent immunoassay for the analysis of betalactam antibiotics. J. Agric. Food Chem., 53, 6635-6642.

Bialk, H.M., Simpson, A.J., and Pedersen, J.A. (2005) Cross-coupling of sulfonamide antimicrobial agents with model humic constituents. Environ. Sci. Technol., 39, 4463-4473.

Blanco, E., Casais, M.C., Mejuto, M.C., and Cela, R. (2005a) Analysis of tetrabromobisphenol A and other phenolic compounds in water samples by non-aqueous capillary electrophoresis coupled to photodiode array ultraviolet detection. J. Chrom. A, 1071, 205-211.

Blanco, E., Casais, M.C., Mejuto, M.C., and Cela, R. (2005b) Comparative study of aqueous and non-aqueous capillary electrophoresis in the separation of halogenated phenolic and bisphenolic compounds in water samples. J. Chrom. A, 1068, 189-199. 
Boyd, G.R., Zhang, S., and Grimm, D. (2005) Naproxen removal from water by chlorination and biofilm processes. Water Res., 39, 668-676.

Braga, O., Smythe, G.A., Schäfer, A.I., and Feitz, A.J. (2005a), Fate of steroid estrogens in Australian inland and coastal wastewater treatment plants. Environ. Sci. Technol, 39, 3351-3358.

Braga, O., Smythe, G.A., Schäfer, A.I., and Feitz, A.J. (2005b), Steroid estrogens in ocean sediments. Chemosphere, 61, 827833.

Braga, O., Smythe, G.A., Schäfer, A.I., and Feitz, A.J. (2005c), Steroid estrogens in primary and tertiary wastewater treatment plants. Water Sci. Technol., 52, 273-278.

Bravo, J.C., Fernandez, P., and Durand, J.S. (2005) Flow injection fluorimetric determination of -estradiol using a molecularly imprinted polymer. Analyst, 130, 1404-1409.

Brossa, L., Marcé, R.M., Borrull, F., and Pocurull, E. (2005) Occurrence of twenty-six endocrine-disrupting compounds in environmental water samples from Catalonia, Spain. Environ. Toxicol. Chem., 24, 261-267.

Bruchet, A., Hochereau, C., Picard, C., Decottignies, V., Rodrigues, J.M., and Janex-Habibi, M.L. (2005) Analysis of drugs and personal care products in French source and drinking waters: the analytical challenge and examples of application. Water Sci. Technol., 52(8), 53-61.

Burgess, R.M., Pelletier, M.C., Gundersen, J.L., Perron, M.M., and Ryba, S.A. (2005) Effects of different forms of organic carbon on the partitioning and bioavailability of nonylphenol. Environ. Toxicol. Chem., 24, 1609-1617.

Buser, H.R., Muller, M.D., Balmer, M.E., Poiger, T., and Buerge, I.J. (2005) Stereoisomer composition of the chiral UV filter 4methylbenzylidene camphor in environmental samples. Environ. Sci. Technol., 39, 3013-3019.

Canosa, P., Rodriguez, I., Rubi, E., and Cela, R. (2005) Optimization of solid-phase microextraction conditions for the determination of triclosan and possible related compounds in water samples. $J$.

Chrom. A, 1072, 107-115.
Cantero, M., Rubio, S., Perez-Bendito, D. (2005) Determination of non-ionic polyethoxylated surfactants in wastewater and river water by mixed hemimicelle extraction and liquid chromatography-ion trap mass spectrometry. J. Chrom. A, 1067, 161-170.

Carballa, M., Omil, F., Lema, J.M., Llompart, M., Garcia, C., Rodriguez, I., Gomez, M., and Ternes, T. (2005) Behaviour of pharmaceuticals and personal care products in a sewage treatment plant of northwest Spain. Water Sci. Technol., 52, 2935.

Cardoza, L.A., Knapp, C.W., Larive, C.K., Belden, J.B., Lydy, M., and Graham, D.W. (2005) Factors affecting the fate of ciprofloxacin in aquatic field systems. Water Air Soil Pollution, $161,383-398$.

Caro, E., Marce, R.M., Cormack, P.A.G., Sherrington, D.C., and Borrull, F. (2005) Selective enrichment of anti-inflammatory drugs from river water samples by solid-phase extraction with a molecularly imprinted polymer. J. Sep. Sci., 28, 2080-2085.

Casey, F. X. M., Šim nek, J., Lee, J., Larsen, G. L., and Hakk, H. (2005) Sorption, mobility, and transformation of estrogenic hormones in natural soil. J. Environ. Qual., 34, 1372-1379.

Castiglioni, S., Bagnati, R., Calamari, D., Fanelli, R., and Zuccato, E. (2005) A multiresidue analytical method using solid-phase extraction and high-pressure liquid chromatography tandem mass spectrometry to measure pharmaceuticals of different therapeutic classes in urban wastewaters. J. Chrom. A, 1092, 206-215.

Céspedes, R., Lacorte, S., Raldúa, D., Ginebreda, A., Barceló, D., and Piña, B. (2005) Distribution of endocrine disruptors in the Llobregat River basin (Catalonia, NE Spain). Chemosphere, 61, $1710-1719$.

Cha, J.M., Yang, S., and Carlson, K.H. (2005) Rapid analysis of trace levels of antibiotic polyether ionophores in surface water by solid-phase extraction and liquid chromatography with ion trap tandem mass spectrometric detection. J. Chrom. A, 1065, 187198. 
Chang, B.V., Chiang, F., and Yuan, S.Y. (2005a) Anaerobic degradation of nonylphenol in sludge. Chemosphere, 59, 14151420

Chang, B.V., Chiang, F., and Yuan, S.Y. (2005b) Biodegradation of nonylphenol in sewage sludge. Chemosphere, 60, 1652-1659.

Chang, B.V., Chiang, F., and Yuan, S.Y. (2005c) Anaerobic degradation of diethyl phthalate, di-n-butyl phthalate, and di-(2ethylhexyl) phthalate from river sediment in Taiwan. Chemosphere, 58, 1601-1607.

Chang, B.V., Liao, G.S., and Yuan, S.Y. (2005d) Anaerobic degradation of di-n-butyl phthalate and di-(2-ethylhexyl) phthalate in sludge. Bull. Environ. Contam. Toxicol., 75, 775782.

Choi, K.J., Kim, S.G., Kim, C.W., and Kim, S.H. (2005) Effects of activated carbon types and service life on removal of endocrine disrupting chemicals: amitrol, nonylphenol, and bisphenol-A. Chemosphere, 58, 1535-1548.

Chu, S.G., Haffner, G.D., and Letcher, R.J. (2005) Simultaneous determination of tetrabromobisphenol A, tetrachlorobisphenol A, bisphenol A and other halogenated analogues in sediment and sludge by high performance liquid chromatographyelectrospray tandem mass spectrometry. J. Chrom. A, 1097, 2532.

Clara, M., Kreuzinger, N., Strenn, B., Gans, O., and Kroiss, H. (2005a) The solids retention time - a suitable design parameter to evaluate the capacity of wastewater treatment plants to remove micropollutants. Water Res., 39, 97-106.

Clara, M., Strenn, B., Gans, O., Martinez, E., Kreuzinger, N., and Kroiss, H. (2005b) Removal of selected pharmaceuticals, fragrances and endocrine disrupting compounds in a membrane bioreactor and conventional wastewater treatment plants. Water Res., 39, 4797-4807.

Comoretto, L. and Chiron, S. (2005) Comparing pharmaceutical and pesticide loads into a small Mediterranean river. Sci. Total Environ., 349(1-3), 201-210.
Davis, J.W., Gonsior, S., Marty, G., and Ariano, J. (2005) The transformation of hexabromocyclododecane in aerobic and anaerobic soils and aquatic sediments. Water Res., 39, 10751084.

Deborde, M., Rabouan, S., Duguet, J.-P., and Legube, B. (2005) Kinetics of Aqueous Ozone-Induced Oxidation of Some Endocrine Disruptors. Environ. Sci. Technol., 39, 6086-6092.

Debrauwer, L., A. Riu, M. Jouahri, E. Rathahao, I. Jouanin, J.-P. Antignac, R. Cariou, B. Le Bizec, and D. Zalko (2005) Probing new approaches using atmospheric pressure photo ionization for the analysis of brominated flame retardants and their related degradation products by liquid chromatography-mass spectrometry. J. Chrom. A, 1082, 98-109.

Debska, J., Kot-Wasik, A., and Namiesnik, J. (2005) Determination of nonsteroidal antiinflammatory drugs in water samples using liquid chromatography coupled with diode-array detector and mass spectrometry. J. Sep. Sci., 28, 2419-2426.

Di Gennaro, P., Collina, E., Franzetti, A., Lasagni, M., Luridiana, A., Pitea, D., and Bestetti, G. (2005) Bioremediation of diethylhexyl phthalate contaminated soil: A feasibility study in slurry- and solid-phase reactors. Environ. Sci. Technol., 39, 325330.

Díaz-Cruz, M.S. and Barceló, D. (2005) LC-MS² trace analysis of antimicrobials in water, sediment and soil. TRAC-Trends Anal. Chem., 24, 645-657.

Dietze, J.E., Scribner, E.A., Meyer, M.T., and Kolpin, D.W. (2005) Occurrence of antibiotics in water from 13 fish hatcheries, 2001-2003. Int. J. Environ. Anal. Chem., 85, 1141-1152.

Dodd, M.C., Shah, A.D., Von Gunten, U., and Huang, C.H. (2005) Interactions of fluoroquinolone antibacterial agents with aqueous chlorine: Reaction kinetics, mechanisms, and transformation pathways. Environ. Sci. Technol., 39, 70657076.

Drewes, J., Hemming, J., Ladenburger, S.J., Schauer, J., and Sonzogni, W. (2005) An assessment of endocrine disrupting activity changes during wastewater treatment through the use of 
bioassays and chemical measurements. Water Environ. Res., 77, $12-23$.

Drillia, P., Dokianakis, S.N., Fountoulakis, M.S., Kornaros, M., Stamatelatou, K., and Lyberatos, G. (2005a) On the occasional biodegradation of pharmaceuticals in the activated sludge process: The example of the antibiotic sulfamethoxazole. $J$. Haz. Materials, 122, 3, 259-265.

Drillia, P., Stamatelatou, K., and Lyberatos, G. (2005b) Fate and mobility of pharmaceuticals in solid matrices. Chemosphere, 60, 1034-1044.

Eichhorn, P., Ferguson, P.L., Pérez, S., and Aga, D.S. (2005) Application of ion trap-MS with QqTOF-MS in the identification H/D exchange and of microbial degradates of trimethoprim in nitrifying activated sludge. Anal. Chem., 77, $4176-4184$

Eljarrat, E., De La Cal, A., Larrazabal, D., Fabrellas, B., FernandezAlba, A.R., Borrull, F., Marce, R.M., and Barcelo, D. (2005) Occurrence of polybrominated diphenylethers, polychlorinated dibenzo-p-dioxins, dibenzofurans and biphenyls in coastal sediments from Spain. Environ. Pollution, 136, 493-501.

Ezra, S.., Feinstein, S., Bilkis, I., Adar, E., and Ganor, J. (2005) Chemical transformation of 3-Bromo-2,2-bis(bromomethyl)propanol under basic conditions. Environ. Sci. Technol., 39, 505-512.

Farre, M., Brix, R., and Barcelo, D. (2005) Screening water for pollutants using biological techniques under European Union funding during the last 10 years. TRAC-Trends Anal. Chem., 24, $532-545$.

Ferdig, M, Kaleta, A, and Buchberger, W. (2005) Improved liquid chromatographic determination of nine currently used (fluoro)quinolones with fluorescence and mass spectrometric detection for environmental samples. J. Sep. Sci., 28, 14481456.

Figueroa, R.A. and Mackay, A.A. (2005) Sorption of oxytetracycline to iron oxides and iron oxide-rich soils. Environ. Sci. Technol., 39, 6664-6671.
Fono, L.J. and Sedlak, D.L. (2005) Use of the chiral pharmaceutical propranolol to identik sewage discharges into surface waters. Environ. Sci. Technol., 39, 9244-9252.

Fontanals, N., Marce, R.M., and Borrull, F. (2005) New hydrophilic materials for solid-phase extraction. TRAC-Trends Anal. Chem., 24, 394-406.

Fountoulakis, M., Drillia, P., Pakou, C., Kampioti, A., Stamatelatou, K., and Lyberatos, G. (2005) Analysis of nonylphenol and nonylphenol ethoxylates in sewage sludge by high performance liquid chromatography following microwave-assisted extraction. J. Chrom. A, 1089, 45-51.

Gao, J. and Pedersen, J.A. (2005) Adsorption of sulfonamide antimicrobial agents to clay minerals. Environ. Sci. Technol., 39, 9509-9516.

Garcia-Reyero, N., Pina, B., Grimalt, J.O., Fernandez, P., Fonts, R., Polvillo, O., and Martrat, B. (2005) Estrogenic activity in sediments from European mountain lakes. Environ. Sci. Technol., 39, 1427-1435.

Gerecke, A.C., Hartmann, P.C., Heeb, N.V., Kohler, H.E., Giger, W., Schmid, P., Zennegg, M., and Kohler, M. (2005) Anaerobic degradation of decabromodiphenyl ether. Environ. Sci. Technol., 39, 4, 1079-1083.

Gibson, R., Wang, M.-J., Padgett, E., and Beck, A.J. (2005) Analysis of 4-nonylphenols, phthalates, and polychlorinated biphenyls in soils and biosolids. Chemosphere, 61, 1336-1344.

Glassmeyer, S.T., Furlong, E.T., Kolpin, D.W., Cahill, J.D., Zaugg, S.D., Werner, S.L., Meyer, M.T., and Kryak, D.D. (2005) Transport of chemical and microbial compounds from known wastewater discharges: potential for use as indicators of human fecal contamination. Environ. Sci. Technol., 39, 5157-5169.

Göbel, A., Thomsen, A., McArdell, C.S., Alder, A.C., Giger, W., Theiss, N., Löffler, D., and Ternes, T.A. (2005a) Extraction and determination of sulfonamides, macrolides, and trimethoprim in sewage sludge. J. Chrom. A, 1085, 179-189.

Göbel, A., Thomsen, A., Mcardell, C.S., Joss, A., and Giger, W. (2005b) Occurrence and sorption behavior of sulfonamides, 
macrolides, and trimethoprim in activated sludge treatment. Environ. Sci. Technol., 39, 3981-3989.

Gomes, R.L., Birkett, J.W., Scrimshaw, M.D., and Lester, J.N. (2005) Simultaneous determination of natural and synthetic steroid estrogens and their conjugates in aqueous matrices by liquid chromatography/mass spectrometry. Intern. J. Environ. Anal. Chem., 85, 1-14.

Gray, J.L., and Sedlak, D.L. (2005) The fate of estrogenic hormones in an engineered treatment wetland with dense macrophytes. Water Environ. Res.,, 77, 24-31.

Gu, J.D., Li, J., and Wang, Y. (2005) Biochemical pathway and degradation of phthalate ester isomers by bacteria. Water Sci. Technol., 52, 241-248.

Guo, B.Y., Wen, B., Shan, X.Q., Zhang, S.Z., and Lin, J.M. (2005) Separation and determination of phthalates by micellar electrokinetic chromatography. J. Chrom. A, 1095, 189-192.

Hakk, H., Millner, P., and Larsen, G. (2005) Decrease in watersoluble 17 -estradiol and testosterone in composted poultry manure with time. J. Environ. Qual., 34, 943-950.

Halden, R.U., and Paull, D.H. (2005) Co-occurrence of triclocarban and triclosan in US water resources. Environ. Sci. Technol., 39, $1420-1426$

Halling-Sørensen, B., Jacobsen, A.M., Jensen, J., Sengelov, G., Vaclavik, E., and Ingerslev, F. (2005) Dissipation and effects of chlortetracycline and tylosin in two agricultural soils: A fieldscale study in southern Denmark. Environ. Toxicol. Chem., 24, $802-810$

Hamscher, G., Pawelzick, H.T., Hoper, H., and Nau, H. (2005) Different behavior of tetracyclines and sulfonamides in sandy soils after repeated fertilization with liquid manure. Environ. Toxicol. Chem., 24, 861-868.

Hann, S., Stefanka, Z., Lenz, K., and Stingeder, G. (2005) Novel separation method for highly sensitive speciation of cancerostatic platinum compounds by HPLC-ICP-MS. Anal. Bioanal. Chem., 381, 405-412.
Hari, A.C., Paruchuri, R.A., Sabatini, D.A., and Kibbey, T.C.G. (2005) Effects of $\mathrm{pH}$ and cationic and nonionic surfactants on the adsorption of pharmaceuticals to a natural aquifer material. Environ. Sci. Technol., 39, 2592-2598.

Hashimoto, S., Akatsuka, Y., Kurihara, R., Matsuoka, S., Nakatsukuri, M., Kurokawa, Y., Tani, Y., and Kawai, S. (2005) Evaluation of the Ishikawa cell line bioassay for the detection of estrogenic substances from sediment extracts. Environ. Toxicol. Chem., 24, 1587-1593.

Hayashi, S., Saito, S., Kim, JH., Nishimura, O., and Sudo, R. (2005) Aerobic biodegradation behavior of nonylphenol polyethoxylates and their metabolites in the presence of organic matter. Environ. Sci. Technol., 39, 5626-5633.

Hirooka, T., Nagase, H., Uchida, K., Hiroshige, Y., Ehara, Y., Nishikawa, J., Nishihara, T., Miyamoto, K., and Hirata, Z. (2005) Biodegradation of bisphenol A and disappearance of its estrogenic activity by the green alga Chlorella fusca var. vacuolata. Environ. Toxicol. Chem., 24, 1896-1901.

Hoh, E., Zhu, L., and Hites, R.A. (2005) Novel Flame Retardants, 1,2-bis(2,4,6-tribromophenoxy)-ethane and 2,3,4,5,6pentabromoethylbenzene, in United States' environmental samples. Environ. Sci. Technol., 39, 2472-2477.

Hu, J., Zhang, H., and Chang, H. (2005) Improved method for analyzing estrogens in water by liquid chromatographyelectrospray mass spectrometry. J. Chrom. A, 1070, 221-224.

Huber, M.M., Göbel, A., Joss, A., Hermann, N., Löffler, D., Mcardell, C.S., Ried, A., Siegrist, H., Ternes, T.A., and von Gunten, U. (2005a) Oxidation of pharmaceuticals during ozonation of municipal wastewater effluents: A pilot study. Environ. Sci. Technol., 39, 4290-4299.

Huber, M.M., Korhonen, S., Ternes, T.A., and von Gunten, U. (2005b) Oxidation of pharmaceuticals during water treatment with chlorine dioxide. Water Res., 39, 3607-3617.

Ieda, T., Horii, Y., Petrick, G., Yamashita, N., Ochiai, N., and Kannan, K. (2005) Analysis of nonylphenol isomers in a technical mixture and in water by comprehensive two- 
dimensional gas chromatography-mass spectrometry. Environ. Sci. Technol., 39, 7202-7207.

Jacobsen, A.M., Lorenzen, A., Chapman, R., and Topp, E. (2005) Persistence of testosterone and 17 -estradiol in soils receiving swine manure or municipal biosolids. J. Environ. Qual., 34, 861-871.

Jiang, J.Q., Yin, Q., Pearce, P. and Zhou, J. (2005a) A survey of endocrine disrupting chemicals in sewage and a preliminary treatment trial. Wat. Sci. Technol., 52, 1-7.

Jiang, J.Q., Yin, Q., Zhou, J.L., and Pearce, P. (2005b) Occurrence and treatment trials of endocrine disrupting chemicals (EDCs) in wastewaters. Chemosphere, 61, 544-550.

Johnson, A.C., Aerni, H.-R., Gerritsen, A., Gibert, M., Giger, W., Hylland, K., Jürgens, M., Nakari, T., Pickering, A., Suter, M.J.F., Svenson, A., and Wettstein, F.E. (2005) Comparing steroid estrogen, and nonylphenol content across a range of European sewage plants with different treatment and management practices. Water Res., 39, 47-58.

Jones, A.D., Bruland, G.L., Agrawal, S.G., and Vasudevan, D. (2005a) Factors influencing the sorption of oxytetracycline to soils. Environ. Toxicol. Chem., 24, 761-770.

Jones, O.A., Lester, J.N., and Voulvoulis, N. (2005b) Pharmaceuticals: a threat to drinking water? Trends Biotechnol., 23, 163-167.

Jones, O.A.H., Voulvoulis, N., and Lester, J.N. (2005c) Human pharmaceuticals in wastewater treatment processes. Crit. Rev. Environ. Sci. Technol., 35, 401-427.

Joss, A., Keller, E., Alder, A.C., Göbel, A., McArdell, C.S., Ternes, T., and Siegrist, H. (2005) Removal of pharmaceuticals and fragrances in biological wastewater treatment. Water Res., 39, 3139-3152.

Kang, J.H. and Kondo, F. (2005) Bisphenol A degradation in seawater is different from that in river water. Chemosphere, $\mathbf{6 0}$, 1288-1292.

Kawaguchi, M., Sakui, N., Okanouchi, N., Ito, R., Saito, K., and Nakazawa, H. (2005) Stir bar sorptive extraction and trace analysis of alkylphenols in water samples by thermal desorption with in tube silylation and gas chromatography-mass spectrometry. J. Chrom. A, 1062, 23-29.

Kay, P., Blackwell, P.A., and Boxall, A.B.A. (2005a) A lysimeter experiment to investigate the leaching of veterinary antibiotics through a clay soil and comparison with field data. Environ. Pollution, 134, 333-341.

Kay, P., Blackwell, P.A., and Boxall, A.B.A. (2005b) Column studies to investigate the fate of veterinary antibiotics in clay soils following slurry application to agricultural land. Chemosphere, 60, 497-507.

Kay, P., Blackwell, P.A., and Boxall, A.B.A. (2005c) Transport of veterinary antibiotics in overland flow following the application of slurry to arable land. Chemosphere, 59, 951-959.

Kim, S., Eichhorn, P., Jensen, J.N., Weber, A.S., and Aga, D.S. (2005) Removal of antibiotics in wastewater: Effect of hydraulic and solid retention times on the fate of tetracycline in the activated sludge process. Environ. Sci. Technol., 39, 58165823.

Kim, S.C. and Carlson, K. (2005) LC-MS ${ }^{2}$ for quantifying trace amounts of pharmaceutical compounds in soil and sediment matrices. TRAC-Trends Anal. Chem., 24, 635-644.

Kloepfer, A., Quintana, J.B., and Reemtsma, T. (2005) Operational options to reduce matrix effects in liquid chromatographyelectrospray ionization-mass spectrometry analysis of aqueous environmental samples. J. Chrom. A, 1067, 153-160.

Knapp, C.W., Cardoza, L.A., Hawes, J.N., Wellington, E.M.H., Larive, C.K., and Graham, D.W. (2005) Fate and effects of enrofloxacin in aquatic systems under different light conditions. Environ. Sci. Technol., 39, 9140-9146.

Koch, D.E., Bhandari, A., Close, L., and Hunter, R.P. (2005) Azithromycin extraction from municipal wastewater and quantitation using liquid chromatography/mass spectrometry. $J$. Chrom. A, 1074, 17-22.

Koester, C.J. and Moulik, A. (2005) Trends in environmental analysis. Anal. Chem., 77, 3737-3754. 
Kojima, M., Matsui, N., Tsunoi, S., and Tanaka, M. (2005) Ion-pair solid-phase extractive derivatization of 4-alkylphenols with pentafluoropyridine for gas chromatography-mass spectrometry. J. Chrom. A, 1078, 1-6.

Kolz, A.C., Moorman, T.B., Ong, S.K., Scoggin, K.D., and Douglass, E.A. (2005a) Degradation and metabolite production of tylosin in anaerobic and aerobic swine-manure lagoons. Water Environ. Res., 77, 49-56.

Kolz, A.C., Ong, S.K., and Moorman, T.B. (2005b) Sorption of tylosin onto swine manure. Chemosphere, 60, 284-289.

Korytár, P., Covaci, A., de Boer, J., Gelbin, A., and Brinkman, U. A.Th. (2005) Retention-time database of 126 polybrominated diphenyl ether congeners and two Bromkal technical mixtures on seven capillary gas chromatographic columns. J. Chrom. A, 1065, 239-249.

Kreuzig, R. and Höltge, S. (2005) Investigations on the fate of sulfadizine in manured soil: laboratory experiments and test plot studies. Environ. Toxicol. Chem., 24, 771-776.

Kreuzig, R., Höltge, S., Brunotte, J., Berenzen, N., Wogram, J., and Schulz, R. (2005) Test-plot studies on runoff of sulfonamides from manured soils after sprinkler irrigation. Environ. Toxicol. Chem., 24, 777-781.

Kwon, J.W. and Armbrust, K.L. (2005) Degradation of citalopram by simulated sunlight. Environ. Toxicol. Chem., 24, 1618-1623.

Labadie, P. and Budzinski, H. (2005) Determination of Steroidal Hormone Profiles along the Jalle d'Eysines River (near Bordeaux, France). Environ. Sci. Technol., 39, 5113-5119.

Lam, M.W., Young, C.J., and Mabury, S.A. (2005) Aqueous photochemical reaction kinetics and transformations of fluoxetine. Environ. Sci. Technol., 39, 513-522.

Langford, K.H., Scrimshaw, M.D., Birkett, J.W., and Lester, J.N. (2005a) Degradation of nonylphenolic surfactants in activated sludge batch tests. Water Res., 39, 870-876.

Langford, K.H., Scrimshaw, M.D., Birkett, J.W., and Lester, J.N. (2005b) The partitioning of alkylphenolic surfactants and polybrominated diphenyl ether flame retardants in activated sludge batch tests. Chemosphere, 61, 1221-1230.

Lau, T.K., Chu, W., and Graham, N. (2005) The degradation of endocrine disruptor di-n-butyl phthalate by UV irradiation: A photolysis and product study. Chemosphere, 60, 1045-1053.

Lee, H.-B., Peart, T.E., and Svoboda, M.L. (2005a) Determination of endocrine-disrupting phenols, acidic pharmaceuticals, and personal-care products in sewage by solid-phase extraction and gas chromatography-mass spectrometry. J. Chrom. A, 1094, 122-129.

Lee, Y., Yoon, J., and Von Gunten, U. (2005b) Kinetics of the oxidation of phenols and phenolic endocrine disruptors during water treatment with ferrate (Fe(VI)). Environ. Sci. Technol., 39, 8978-8984.

Leskinen, P., Michelini, E., Picard, D., Karp, M., and Virta, M. (2005) Bioluminescent yeast assays for detecting estrogenic and androgenic activity in different matrices. Chemosphere, 61, 259-266.

Leusch, F.D.L., Chapman, H.F., Korner, W., Gooneratne, S.R., and Tremblay, L.A. (2005) Efficacy of an advanced sewage treatment plant in Southeast Queensland, Australia, to remove estrogenic chemicals. Environ. Sci. Technol., 39, 5781-5786.

Li, F., Yuasa, A., Obara, A., and Mathews, A.P. (2005) Aerobic batch degradation of 17- estradiol (E2) by activated sludge: Effects of spiking E2 concentrations, MLVSS and temperatures. Water Res., 39, 2065-2075.

Lin, A.Y.-C. and Reinhard, M. (2005) Photodegradation of common environmental pharmaceuticals and estrogens in river water. Environ. Toxicol. Chem., 24, 1303-1309.

Lindberg, R.H., Wennberg, P., Johansson, M.I., Tysklind, M., and Andersson, B.A.V. (2005) Screening of human antibiotic substances and determination of weekly mass flows in five sewage treatment plants in Sweden. Environ. Sci. Technol., 39, 3421-3429. 
Lindqvist, N., Tuhkanen, T., and Kronberg, L. (2005) Occurrence of acidic pharmaceuticals in raw and treated sewages and in receiving waters. Water Res., 39, 2219-2228.

Liu, R.X., Wilding, A., Hibberd, A., and Zhour, J.L. (2005a) Partition of endocrine-disrupting chemicals between colloids and dissolved phase as determined by cross-flow ultrafiltration. Environ. Sci. Technol., 39, 2753-2761.

Liu, S.M., Lin, Y.L., and Chi, W.C. (2005b) The effects of benzoate, cyclohex-1-ene carboxylate, and cyclohexane carboxylate on biotransformation of o-phthalate in sediment slurries under sulfate-reducing conditions. Chemosphere, 59, 41-48.

Liu, S.M., Lin, Y.L., and Tsai, T.L. (2005c) Growth dynamics of major microbial populations during biodegradation of ophthalate in anaerobic sediment slurries under a $\mathrm{CO}_{2} / \mathrm{H}_{2}$ atmosphere. Chemosphere, 59, 91-98.

Loffler, D., Rombke, J., Meller, M., and Ternes, T.A. (2005) Environmental fate of pharmaceuticals in water/sediment systems. Environ. Sci. Technol., 39, 5209-5218.

Loftin, K.A., Henny, C., Adams, C.D., Surampali, R., and Mormile, M.R. (2005) Inhibition of microbial metabolism in anaerobic lagoons by selected sulfonamides, tetracyclines, lincomycin, and tylosin tartrate. Environ. Toxicol. Chem., 24, 782-788.

Lorenzen, A., Chapman, R., Hendel, J.G., and Topp, E. (2005) Persistence and Pathways of Testosterone Dissipation in Agricultural Soils. J. Environ. Qual., 34, 854-860.

MacKay, A.A. and Canterbury, B. (2005) Oxytetracycline sorption to organic matter by metal-bridging. J. Environ. Qual., 34, 19641971.

Mai, B., Chen, S., Luo, X., Chen, L., Yang, Q., Sheng, G., Peng, P., Fu, J., and Zeng, E.Y. (2005) Distribution of polybrominated diphenyl ethers in sediments of the Pearl River Delta and adjacent South China Sea. Environ. Sci. Technol., 39, 35213527.

McDowell, D.C., Huber, M.M., Wagner, M., Von Gunten, U., and Ternes, T.A. (2005) Ozonation of carbamazepine in drinking water: Identification and kinetic study of major oxidation products. Environ. Sci. Technol., 39, 8014-8022.

Miao, X.S., Yang, J.J., and Metcalfe, D.C. (2005) Carbamazepine and its metabolites in wastewater and in biosolids in a municipal wastewater treatment plant. Environ. Sci. Technol., 39, 74697475.

Michelini, E., Leskinen, P., Virta, M., Karp, M., and Roda, A. (2005) A new recombinant cell-based bioluminescent assay for sensitive androgen-like compound detection. Biosensors Bioelectron., 20, 2261-2267.

Mitani, K., Fujioka, A., and Kataoka, H. (2005) Fully automated analysis of estrogens in environmental waters by in-tube solidphase microextraction coupled with liquid chromatographytandem mass spectrometry. J. Chrom. A, 1081, 218-224.

Moral, A., Sicilia, M.D., Rubio, S., and Pérez-Bendito, D. (2005) Determination of bisphenols in sewage based on supramolecular solid-phase extraction/liquid chromatography/fluorimetry. $J$. Chrom. A, 1100, 8-14.

Nakata, H., Kannan, K., Jones, P.D., and Giesy, J.P. (2005) Determination of fluoroquinolone antibiotics in wastewater effluents by liquid chromatography-mass spectrometry and fluorescence detection. Chemosphere, 58, 759-766.

Namie nik, J., Zabiega a, B., Kot-Wasik, A., Partyka, M., and Wasik, A. (2005) Passive sampling and/or extraction techniques in environmental analysis: a review. Anal. Bioanol. Chem., 381, 279-301.

Oliver, R., May, E., and Williams, J. (2005) The occurrence and removal of phthalates in a trickle filter STW. Water Res. 39, 4436-4444.

Oros, D.R., Hoover, D., Rodigari, F., Crane, D., and Sericano, J. (2005) Levels and distribution of polybrominated diphenyl ethers in water, surface sediments, and bivalves from the San Francisco Estuary. Environ. Sci. Technol., 39, 33-41.

Overcash, M., Sims, R.C., Sims, J.L, and Nieman, J.K.C. (2005) Beneficial reuse and sustainability: the fate of organic compounds in land-applied waste. J. Environ. Qual., 34, 29-41. 
Pedersen, J.A., Soliman, M., and Suffet, I.H. (2005) Human pharmaceuticals, hormones, and personal care product ingredients in runoff from agricultural fields irrigated with treated wastewater. J. Agric. Food Chem., 53, 1625-1632.

Pepich, B.V., Prakash, B., Domino, M.M., Dattilio, T.A., Munch, D.J., and Price, E.K. (2005) Development of US EPA method 527 for the analysis of selected pesticides and flame retardants in the UCMR survey. Environ. Sci. Technol., 39, 4996-5004.

Pérez, S., Eichhorn, P., and Aga, D.S. (2005) Evaluating the biodegradability of sulfamethazine, sulfamethoxazole, sulfathiazole, and trimethoprim at different stages of sewage treatment. Environ. Toxicol. Chem., 24, 1361-1367.

Petrovi , M., Hernando, M.D., Díaz-Cruz, M.S., and Barceló, D. (2005) Liquid chromatography-tandem mass spectrometry for the analysis of pharmaceutical residues in environmental samples: a review. J. Chrom. A, 1067, 1-14.

Pillon, A., Boussioux, A.M., Escande, A., Ait-Aissa, S., Gomez, E., Fenet, H., Ruff, M., Moras, D., Vignon, F., Duchesne, M.J., Casellas, C., Nicolas, J.C., and Balaguer, P. (2005) Binding of estrogenic compounds to recombinant estrogen receptor-alpha: Application to environmental analysis. Environ. Health Perspect., 113, 278-284.

Polo, M., Llompart, M., Garcia-Jares, C., and Cela, R. (2005) Multivariate optimization of a solid-phase microextraction method for the analysis of phthalate esters in environmental waters. J. Chrom. A, 1072, 63-72.

Proll, G., Tschmelak, J., and Gauglitz, G. (2005) Fully automated biosensors for water analysis. Anal. Bioanal. Chem., 381, 61-63.

Quintana, J.B., Weiss, S., and Reemtsma, T. (2005) Pathways and metabolites of microbial degradation of selected acidic pharmaceutical and their occurrence in municipal wastewater treated by a membrane bioreactor. Water Res. 39, 2654-2664.

Quiros, L., Cespedes, R., Lacorte, S., Viana, P., Raldua, D., Barcelo, D., and Pina, B. (2005) Detection and evaluation of endocrinedisruption activity in water samples from Portuguese rivers. Environ. Toxicol. Chem., 24, 389-395.
Reddy, S. and Brownawell, B.J. (2005) Analysis of estrogens in sediment from a sewage-impacted urban estuary using highperformance liquid chromatography/time-of-flight mass spectrometry. Environ. Toxicol. Chem., 24, 1041-1047.

Reddy, S., Iden, C.R., and Brownawell, B.J. (2005) Analysis of steroid conjugates in sewage influent and effluent by liquid chromatography-tandem mass spectrometry. Anal. Chem., 77, 7032-7038.

Richardson, S.D. and Ternes, T.A. (2005) Water analysis: emerging contaminants and current issues. Anal. Chem., 77, 3807-3838.

Rodriguez-Mozaz, S., Lopez de Alda, M., and Barcelo, D. (2005) Analysis of bisphenol A in natural waters by means of an optical immunosensor. Water Res., 39, 5071-5079.

Rule, K.L., Ebbett, V.R., and Vikesland, P.J. (2005) Formation of chloroform and chlorinated organics by free-chlorine-mediated oxidation of triclosan. Environ. Sci. Technol., 39, 3176-3185.

Sablayrolles, C., Montrejaud-Vignoles, M., Benanou, D., Patria, L., and Treilhou, M. (2005) Development and validation of methods for the trace determination of phthalates in sludge and vegetables. J. Chrom. A, 1072, 233-242.

Sacher, F., Raue, B., and Brauch, H.-J. (2005) Analysis of iodinated $\mathrm{X}$-ray contrast agents in water samples by ion chromatography and inductively-coupled plasma mass spectrometry. J. Chrom. $A, \mathbf{1 0 8 5}, 117-123$.

Sanchez-Prado, L., Gonzalez-Barreiro, C., Lores, M., Llompart, M., Garcia-Jares, C., and Cela, R. (2005a) Photochemical studies of a polybrominated diphenyl ethers (PBDES) technical mixture by solid phase microextraction (SPME). Chemosphere, 60, 922928.

Sanchez-Prado, L., Llompart, M., Lores, M., Garcia-Jares, C., and Cela, R. (2005b) Investigation of photodegradation products generated after UV-irradiation of five polybrominated diphenyl ethers using photo solid-phase microextraction. J. Chrom. A, 1071, 85-92.

Scheytt, T., Mersmann, P., Lindstädt, R., and Heberer, T. (2005a) Determination of sorption coefficients of pharmaceutically 
active substances carbamazepine, diclofenac, and ibuprofen, in sandy sediments. Chemosphere, 60, 245-253.

Scheytt, T., Mersmann, P., Lindstädt, R., and Heberer, T. (2005b) 1Octanol/water partition coefficients of 5 pharmaceuticals from human medical care: carbamazepine, clofibric acid, diclofenac, ibuprofen, and propyphenazone. Water Air Soil Pollution, 165, 3-11.

Schlenk, D., Sapozhnikova, Y., Irwin, M.A., Xie, L.T., Hwang, W., Reddy, S., Brownawell, B.J., Armstrong, J., Kelly, M., Montagne, D.E., Kolodziej, E.P., Sedlak, D., and Snyder, S. (2005) In vivo bioassay-guided fractionation of marine sediment extracts from the Southern California Bight, USA, for estrogenic activity. Environ. Toxicol. Chem., 24, 2820-2826.

Schlüsener, M.P. and Bester, K. (2005) Determination of steroid hormones, hormone conjugates and macrolide antibiotics in influents and effluents of sewage treatment plants utilizing highperformance liquid chromatography/tandem mass spectrometry with electrospray and atmospheric pressure chemical ionization. Rapid Comm. Mass Spectrom., 19, 3269-3278.

Schwarzbauer, J. and Heim, S. (2005) Lipophilic organic contaminants in the Rhine river, Germany. Water Res., 39, $4735-4748$

Sellstrom, U., De Wit, C.A., Lundgren, N., and Tysklind, M. (2005) Effect of sewage-sludge application on concentrations of higher-brominated diphenyl ethers in solids and earthworms. Environ. Sci. Technol., 39, 9064-9070.

Servos, M.R., Bennie, D.T., Burnison, B.K., Jurkovic, A., McInnis, R., Neheli, T., Schnell, A., Seto, P., Smyth, S.A., and Ternes, T.A. (2005) Distribution of estrogens, 17 -estradiol and estrone, in Canadian municipal wastewater treatment plants . Sci. Total Environ., 336, 155-170.

Song, W., Ford, J.C., Li, A., Sturchio, N.C., Rockne, K.J., Buckley, D.R., and Mills, W.J. (2005a) Polybrominated diphenyl ethers in the sediments of the Great Lakes. 3. Lakes Ontario and Erie. Environ. Sci. Technol., 39, 5600-5605.
Song, W., Li, A., Ford, J.C., Sturchio, N.C., Rockne, K.J., Buckley, D.R., and Mills, W.J. (2005b) Polybrominated diphenyl ethers in the sediments of the Great Lakes. 2. Lakes Michigan and Huron. Environ. Sci. Technol., 39, 3474-3479.

Stoob, K., Singer, H.P., Goetz, C.W., Ruff, M., and Mueller, S.R. (2005) Fully automated online solid phase extraction coupled directly to liquid chromatography-tandem mass spectrometry. $J$. Chrom. A, 1097, 138-147.

Stuer-Lauridsen, F. (2005) Review of passive accumulation devices for monitoring organic micropollutants in the aquatic environment. Environ. Pollution, 136, 503-524.

Suidan, M.T., Esperanza, M., Zein, M., McCauley, P., Brenner, R.C., and Venosa, A.D. (2005) Challenges in biodegradation of trace organic contaminants—gasoline oxygenates and sex hormones. Water Environ. Res., 77, 4-11.

Sumpter, J.P. (2005) Endocrine disrupters in the aquatic environment: An overview. Acta Hydrochim. Hydrobiol., 33, 9-16.

Sumpter, J.P. and Johnson, A.C. (2005) Lessons from endocrine disruption and their application to other issues concerning trace organics in the aquatic environment. Environ. Sci. Technol., 39, $4321-4332$.

Telscher, M.J.H., Schuller, U., Schmidt, B., and Schaffer, A. (2005) Occurrence of a nitro metabolite of a defined nonylphenol isomer in soil/sewage sludge mixtures. Environ. Sci. Technol., 39, 7896-7900

Thomas, P.M. and Foster, G.D. (2005) Tracking acidic pharmaceuticals, caffeine, and triclosan through the wastewater treatment process. Environ. Toxicol. Chem., 24, 25-30.

Tschmelak, J., Proll, G., and Gauglitz, G. (2005) Optical biosensor for pharmaceuticals, antibiotics, hormones, endocrine disrupting chemicals and pesticides in water: Assay optimization process for estrone as example. Talanta, 65, 313-323.

Urase, T. and Kikuta, T. (2005) Separate estimation of adsorption and degradation of pharmaceutical substances and estrogens in the activated sludge process. Water Res., 39, 1289-1300. 
Vermeirssen, E.L.M., Korner, O., Schonenberger, R., Suter, M. J.-F., and Burkhardt-Holm, P. (2005) Characterization of environmental estrogens in river water using a three pronged approach: active and passive water sampling and the analysis of accumulated estrogens in the bile of caged fish. Environ. Sci. Technol., 39, 8191-8198.

Verslycke, T.A., Vethaak, A.D., Arijs, K., and Janssen, C.R. (2005) Flame retardants, surfactants and organotins in sediment and mysid shrimp of the Scheldt estuary (The Netherlands). Environ. Pollution, 136, 19-31.

Vethaak, A.D., Lahr, J., Schrap, S.M., Belfroid, A.C., Rijs, G.B.J., Gerritsen, A., de Boer, J., Bulder, A.S., Grinwis, G.C.M., Kuiper, R.V., Legler, J., Murk, T.A.J., Peijnenburg, W., Verhaar, H.J.M., and de Voogt, P. (2005) An integrated assessment of estrogenic contamination and biological effects in the aquatic environment of The Netherlands. Chemosphere, 59, $511-524$.

Vieno, N.M., Tuhkanen, T., and Kronberg, L. (2005) Seasonal variation in the occurrence of pharmaceuticals in effluents from a sewage treatment plant and in the recipient water. Environ. Sci. Technol., 39, 8220-8226.

Vrana, B., Mills, G.A., Allan, I.J., Dominiak, E., Svensson, K., Knutsson, J., Morrison, G., and Greenwood, R. (2005) Passive sampling techniques for monitoring pollutants in water. TRACTrends Anal. Chem., 24, 845-868.

Wang, D., Cai, Z., Jiang, G., Leung, A., Wong, M.H., and Wong, W.K. (2005) Determination of polybrominated diphenyl ethers in soil and sediment from an electronic waste recycling facility. Chemosphere, 60, 810-816.

Watabe, Y., Hosoya, K., Tanaka, N., Kubo, T., Kondo, T., and Morita, M. (2005) Novel surface modified molecularly imprinted polymer focused on the removal of interference in environmental water samples for chromatographic determination. J. Chrom. A, 1073, 363-370.

Westerhoff, P., Yoon, Y., Snyder, S., and Wert, E. (2005) Fate of endocrine-disruptor, pharmaceutical, and personal care product chemicals during simulated drinking water treatment processes. Environ. Sci. Technol., 39, 6648-6663.

Yang, S.W., Cha, J.M., and Carlson, K. (2005) Simultaneous extraction and analysis of 11 tetracycline and sulfonamide antibiotics in influent and effluent domestic wastewater by solid-phase extraction and liquid chromatography-electro spray ionization tandem mass spectrometry. J. Chrom. A, 1097, 40-53.

Zeng, Z.Q., Shan, T., Tong, Y., Lam, S.H., and Gong, Z. (2005) Development of estrogen-responsive transgenic medaka for environmental monitoring of endocrine disrupters. Environ. Sci. Technol., 39, 9001-9008.

Zhang, Y. and Zhou, J.L. (2005) Removal of estrone and 17 estradiol from water by adsorption. Water Res., 39, 3991-4003.

Zhu, L.Y., and Hites, R.A. (2005) Brominated flame retardants in sediment cores from lakes Michigan and Erie . Environ. Sci. Technol., 39, 3488-3494.

Zuehlke, S., Duennbier, U., and Heberer T. (2005) Determination of estrogenic steroids in surface water and wastewater by liquid chromatography-electrospray tandem mass spectrometry. J. Sep. Sci., 28, 52-58.

Zuo, Y. and Zhang, K. (2005) Suitability of N,Obis(trimethylsilyl)trifluoroacetamide as derivatization reagent for the determination of the estrogens estrone and 17 ethinylestradiol by gas chromatography-mass spectrometry. $J$. Chrom. A, 1095, 201-202. 